\title{
Ship Captains and Sailors
}

After the Treaties of Peace normalized relations with North Africa and the Ottoman Empire, warships and corsair vessels from those countries began to frequent Spanish ports. Most arrived in search of food, water, or repairs, while others formed part of convoys that were escorting merchant ships. Most of these visits created few problems, but we will be describing some conflicts that arose from time to time.

\subsection{Moroccan Captains (arraeces, sg. arráez)}

The Spanish-Moroccan Treaty of Peace, Friendship, and Trade signed in 1767 provided little detail about how warships of the respective countries should be dealt with when they visited a port of the other; only five of its articles address the issue. There were norms that governed encounters on the high seas, and if Moroccan ships should be wrecked on the Spanish coast or vice-versa they would be

treated with all due hospitality while attempting to salvage the vessels if possible, giving them whatever assistance they may request. This help shall be offered gratis or at a fair price. ... Any ship may remain in port as long as it wishes. ... Warships shall be exempt from paying [taxes], anchorage fees, or any other duty.

All Moroccan warships or merchant ships would have to serve a quarantine, unless they could show a patent from the Spanish consul in Tangier declaring that the Moroccan Empire was free of plague at the time. ${ }^{1}$

1 “...[Serán] tratadas con toda buena hospitalidad, procurando, si fuese posible, salvar las embarcaciones, y dándoles los auxilios que para ello pidieren, sin pagarse los trabajos ó lo que franqueen mas que por sus justos precios. ... [C]ualquiera embarcación ha de poder estar en los puertos el tiempo que quisiere. ... [L]as embarcaciones de guerra estarán exentas de pagar ninguno de ellos [los impuestos], ni tampoco anclaje ni otro cualquiera impuesto." The Treaty of Friendship and Trade between Spain and Morocco signed in Aranjuez in 1789 paid scarce attention to warships: Cantillo, Tratados, 505-06, $5^{6} 5^{-68 . .}$ 
The later Peace Treaty of 1799 showed increased attention to warships, which were now mentioned in nine articles. Two of them established that "warships of both nations that meet on the high seas" should assist each other with food, water, "or anything essential to continuing their voyage," though the supplies should be paid for "at the current price." Three more articles stipulated that if either country should capture an enemy ship, subjects and merchandise of either nation found on board could not be sold in a port of the other. Another stressed that quarantine in Spanish ports was obligatory, "following the precautions and formalities established by the authorities to ensure public health." And a further clause addressed shipwrecks, including forced landings

made safely at any inlet that lacks installations, where every effort shall be made to save persons, ships, and cargo. That labor, and the value of any provisions bought, shall be compensated at current prices without duties of any kind.

The last article established that warships of both countries would not pay "fees of anchorage or any other kind in any of [the other's] ports, nor for food, water, wood, charcoal, or refreshments for their consumption."

While the treaties specify that articles bought in Spanish ports should be paid for at "current" or "fair" prices, especially in the early years Spain routinely offered basic "refreshments," water, firewood, and other supplies and repairs to Moroccan warships and shipwrecked vessels without charge. ${ }^{3}$ For instance Hamet, the captain of a Moroccan corsair xebec, reached Barcelona in August 1799, and since "he was unable to disembark to ask for water" the treasury of the army provided him with both water and firewood. ${ }^{4}$

2 “...[A] cualquier rada, en hora buena no esté generalmente habilitada, se les asistirá haciendo lo posible por libertar personas, buques y efectos; cuyo trabajo se satisfará á los precios corrientes, así como el valor de las provisiones que compren sin exigir derecho de ninguna clase. ... [No pagarán] en ninguno de sus puertos mutuamente derecho de ancoraje ni de otra clase por los víveres, aguada, leña, carbón y refrescos que necesiten para su consumo": Cantillo, Tratados, 688-89.

3 Cantillo, Tratados, 685-91. Spanish warships in Moroccan ports enjoyed the same privileges.

4 The cost of renting empty casks and paying the dock workers who loaded the wood and water came to 6 libras and 6 sueldos: "Oficio del Guardián del Puerto," 2 August 1799. Marquis of Vallesantoro to Blas de Aranza, 2 and 19 August 1799, Імнв, FS, Serie I, leg. 21, fol. 143 . 
We do not know exactly how many Moroccan warships docked in Spanish ports during the period under study. ${ }^{5}$ Their presence is documented in Cádiz, Málaga, Cartagena, Barcelona, and other ports. ${ }^{6}$

These landings do not seem to have caused many problems, although some did arise, as we are about to see. We should make clear that both countries did what they could to avoid unpleasant incidents. The Moroccan sultan ordered his captains to patrol the seas constantly in search of prizes, but if an emergency forced them into a Spanish port they should leave as soon as possible: "I have ordered all my captains not to tarry in port in Spain; should they need water they should seek it in the nearest port and then depart." ${ }^{7}$ Moroccan captains were provided with passports so that Spanish warships would not take them for Algerians, and to ensure their welcome in Spanish ports. These documents, signed by Consul Juan Manuel González Salmón, typically read as follows:

Hach Mahamet Farach is captain of one of His Moroccan Majesty's galliots of two guns, twelve rowing benches, and a crew of thirty-nine men. At present it rides at anchor in this port and will soon set sail on the Mediterranean. Be it known to the commanders and other officers of His Catholic Majesty's warships that this galley belongs to the King of Morocco and they should receive and treat it as a friend, and in case of need protect and preserve it as may be necessary. ${ }^{8}$

On several occasions Spanish diplomatic correspondence shows the Moroccans' gratitude for help that their ships and crews had received. In July 1772

5 For the Moroccan navy see Lourido Díaz, Marruecos y el mundo exterior, esp. Chap. 1; also Miège, "Course et marine marocaine."

6 For instance, five Spanish deserters boarded a corsair frigate in Cartagena in May 1774: Tomás Bremond to Marquis of Grimaldi, Salé, 6 May 1774. "Some small Moroccan galliots" entered the Bay of Cádiz in October 1778: Jorge Patissiati to Marquis of Grimaldi, Cádiz, 2o October 1778, AHN, Estado, leg. 4312. Captains al-Farache and al-Hamsaly were in Algeciras in 1781:J.M. González Salmón to Count Floridablanca, 7 January 1781, A HN, Estado, leg. 4314. See also the many other cases narrated in this chapter.

7 Letter from Sidi Mohammed Ben Abdala, in the sultan's name, to T. Bremond, 4 December 1772, AHN, Estado, leg. 3412.

8 "[E]l Harraez el Hach Mahamet Farach lo es de una de las Galeotas de S.M.M. de dos cañones, doce bancos, y treinta y nueve hombres de Tripulacion, que al presente se halla surta en este Puerto, y pronto ha de hacerse a la Vela para el Mediterráneo, y para que conste a los señores Comandantes, y demás oficiales de los Buques de Guerra de S.M.C. pertenece dicha Galera al Rey de Marruecos, y la traten, y atiendan como amiga, y en caso necesario la protexan, y auxilien en lo que necesite": Juan Manuel González Salmón to Count Floridablanca, Tangier, 24 May 1782, AHN, Estado, leg. 4314. 
Morocco's former ambassador to the Spanish court, al-Gazzal, and the sultan's secretary S. Sumbel thanked the Spanish consul in Tangier after Moroccans taken at sea by a Russian ship were succored in Cádiz: "for giving assistance out of the Royal Treasury to the ten Moors who arrived there in a French tartane." 9 In September of that year two Moroccan corsair galliots also received aid in Cádiz: "the rudder of one was repaired and the other was supplied with the water and victuals they requested, paid for by the Royal Treasury." The Spanish consul in Morocco, Tomás Bremond, urged his Secretary of State "to inform His Moroccan Majesty [of it] when convenient, so that he may see how well his vassals are treated in Spain."10 In August 1775 five galliots from Tetouan under Captain Mostaganim docked in Ceuta, where their needs were met. ${ }^{11}$ In the following year a galliot, in difficulties after meeting "a westerly wind and contrary seas, sought shelter in a cove near Ceuta" and received assistance; when the news reached Tetouan "everyone was pleased." ${ }^{2}$ The captain of a frigate that, "badly damaged by bad weather," docked in Cádiz in January 1782 told the governor of Tangier about the "liberality with which [the governor of Cádiz] arranged to have the frigate repaired and supplied the needs of its crew."13 In July of that year Captain Mohamed al-Farache asked Consul González Salmón to recommend him to the governor of Melilla, where he needed to load cannon and mortars for the Moroccan army and transport them to Tangier; assistance was readily granted. Al-Farache arrived in Tangier in 1783 aboard a pink from Málaga, conveying some of the sultan's artillery and war matériel that had been left in Melilla; he was "very satisfied with the help given him gratis" both there and in Málaga, "where he had docked because of contrary winds." ${ }^{14}$ After fortythree Moroccans were shipwrecked on the coast of the Kingdom of Naples in 1784, Spain chartered an English ship in Cartagena to convey them to Tangier. ${ }^{15}$

The king of Spain ordered them sent to Larache: T. Bremond to Marquis of Grimaldi, Larache, 30 July 1772. Al-Gazzal thanked Bremond for his help on 2 August 1772. Also Samuel Sumbel, the sultan's secretary, to T. Bremond, 19 June 1772, AHN, Estado, leg. 3412.

10 T. Bremond to Marquis of Grimaldi, Larache, 18 September 1772. In 1773 five galliots left Tangier after their captains were instructed to resupply in Gibraltar, Algeciras, and Ceuta in case of bad weather: T. Bremond to Marquis of Grimaldi, 8 January 1773, AHN, Estado, leg. 4312.

11 Jorge Patissiati, Spanish vice consul in Tetouan, to Marquis of Grimaldi, Cádiz, 8 and 15 August 1775, AHN, Estado, leg. 4312.

12 Jorge Patissiati to Marquis of Grimaldi, 3 O July 1776, AHN, Estado, leg. 4312.

13 J.M. González Salmón to Count Floridablanca, 2 January 1782, A HN, Estado, leg. 4314.

14 Count of Floridablanca to the Count of Xerena, San Ildefonso [El Escorial], 5 July 1782. J.M. González Salmón to Count Floridablanca, 30 July 1782. Mohamed al-Farache to J.M. González Salmón, Tetouan, 19 September 1782, AHN, Estado, leg. 4314. J.M. González Salmón to Count Floridablanca, Tangier, 8 July 1783, A HN, Estado, leg. 4317.

15 J.M. González Salmón to Count Floridablanca, 27 July 1784, AHN, Estado, leg. 4317. 
The sultan wrote to the Spanish consul general in Tangier in 1786 to thank him for the welcome offered to two captains: Sabuny, whose frigate had called at Cartagena, and Ibrahim Lubaris, who had docked at Algeciras. Both of them

have told us how well they were treated by the Spanish. We have also learned that Captain Lubaris's ship is now in Algeciras and that the Spaniards are receiving him and his crew very well while they are busy repairing it. All this is proof of the true friendship between the Spaniards and ourselves. ${ }^{16}$

Nonetheless, problems developed when captains demanded supplies and repairs, when health regulations had to be imposed, or when Moroccan captains and seamen were held captive in Algerian corsair ships.

Strict sanitary measures imposed in Spanish ports - especially when there was news of an epidemic of plague in any Muslim country in the Mediterranean - gave rise to delays and expenses, and Moroccan ship captains (like their Spanish and foreign counterparts) did whatever they could to evade them. The Peace Treaty of 1767 determined that Moroccan ships reaching Spanish ports should "serve the stipulated quarantine unless the consuls have assured a perfect bill of health, in which case they shall be exempt from it."17 The Treaty of 1799 ratified that agreement, decreeing that Moroccan ships would be admitted to ports in Spain "following the precautions and formalities established by the health authorities to ensure public safety."18

In practice, Moroccan vessels routinely concealed the fact that they had docked in Algerian or other North African ports or had had contact with other Muslims ships at sea, a fact they were required to report. In $177^{2}$ Spanish

16 “...[N]os ha dado parte de lo mucho que lo han agasajado los Españoles. Assi mismo nos llegó la noticia que la Embarcacion del Harraez Luberes [sic], se halla en Algeciras, y que los Españoles lo obsequian mucho como a su tripulación, y que están ocupados en componerla: Todo esto son pruevas de la verdadera amistad de los Españoles con Nosotros": translated letter from the Moroccan sultan to J.M. González Salmón, 13 March 1786, A HN, Estado, leg. 4319. See also Arribas Palau, "El viaje a España del arráez Ibrahim Lubaris."

17 In October 1767 a frigate and a galliot of the Moroccan sultan's reached Cartagena and were placed in quarantine; since the Peace Treaty did not specify its length, it was decided to detain them for ten days so long as there was no news of contagion in Morocco. Later, however, Spanish and Moroccan ships coming from Morocco were admitted if they brought a clean bill of health. If plague was reported in North Africa, authorities were to follow the royal edicts regarding health: printed notice from the Count of Aranda, Madrid, 13 November 1767, Iм нв, Fs, Serie I, leg. 23, fol. 5 o. 
authorities claimed that almost every Moroccan ship denied having "sailed the Mediterranean and stopped in that port of the said Regency [Algiers]."19 In the autumn of 1772 reports from Cartagena and Málaga stated that two frigates, a xebec, and a galliot from Morocco had docked there, captained respectively by Sidi al-Arbi al-Mistiri, Sidi Legaume, Ysmain Tunesi, and Ahmad Mostaganim. All were bearing

patents of health from our consuls, but in neither port did the captains admit to having stopped in Algiers. In this they betrayed the oath and word of honor that is required from the commander of every warship unlike merchant captains, to whom more detailed regulations apply as their cargoes require.

In the face of this "breach of the law by officers under [the Moroccan sultan's] command," Tomás Bremond was ordered to tell him to "issue the strictest orders that commanders of his warships must never fail to declare the ports where they have docked after leaving Morocco, and any contact they may have had with any other ship at sea, on the understanding that if they do not do so and it can be proved, they shall be submitted in our ports to the appropriate quarantine." 20

19 T. Bremond to Marquis of Grimaldi, Larache, 5 December 1772. Count Aranda to Marquis of Grimaldi, 29 December 1772, AHN, Estado, leg. 3412.

$20 \quad$ "...patentes de Sanidad de nuestros consules, sin que en ninguno de dichos dos Puertos ayan manifestado los capitanes, y arráeces haver tocado en Argel, faltando en esto al juramento, y palabra de onor con que está mandado por punto general se tome de los Comandantes de todo Buque de Guerra a diferencia de los del Comercio, con quienes se practican otras diligencias mas menudas qual lo requieren sus cargas. ... [Que el sultán] pueda dar las ordenes mas estrechas para que los Comandantes de sus Buques de Guerra de ningun modo omitan declarar los Puertos en que después de su salida de Marruecos huvieren tocado, y roces que hayan tenido con qualquiera otra nave en su viaje; bien entendido que no hacerlo y si se berificase lo contrario, se les sugetará en nuestros Puertos a la Quarentena que corresponda": Count Aranda to Marquis of Grimaldi, 24 January 1773. "The captains of the ports of Cartagena and Málaga [had] asked the captains of Your Majesty's ships arriving this summer if they had been to Algiers. And upon their saying they had not, on their word of honor and by the oath they had given to tell the truth in the name of Our Lord God, they were admitted at once. But the king my master later learned that those captains had been in Algiers before going to Málaga and Cartagena and had sworn falsely, betraying their word of honor": T. Bremond to the Moroccan sultan, Larache, 23 March 1773. When the captains were asked if they had "touched at [the ports of] the North African Regencies or had had contact with any other ship during their voyage had concealed everything, failing in this the oath and word of honor they had given": T. Bremond to Marquis of Grimaldi, Larache, 24 March 1773, AHN, Estado, leg. 3412. 
The Spanish Court echoed these complaints against the captains, who had no excuse because they knew the health regulations:

[There are] several Moroccan ships whose commanders have failed in their responsibility in this essential matter to the point of denying in our ports that they had docked in Algiers, at great risk to the public health of these kingdoms. ${ }^{21}$

The Moroccan authorities, however, did try to limit such abuses. One such case involves five Moroccan merchants who left Cádiz, three of them without the required health documents. (Let us set aside the fact that they should not have been allowed to sail without them from Algeciras or their port of origin, Cádiz.) When the felucca anchored at Ceuta they were not admitted to port and were threatened with sinking if they did not leave. On arriving in Tangier the Moroccans complained about their treatment at Ceuta to the governor, who in turn consulted the Spanish consul: that official spoke of health as a very "delicate" issue, especially when there was an outbreak of plague in the Levant. The governor, satisfied, "scolded the Moors severely for not having brought up-to-date papers"; he also asked the consul to ensure that in Cádiz "no Moor may embark without that requirement, for many of them do not know that it is necessary."22

Another issue was the fairly frequent presence of Moroccans aboard Algerian corsair ships. When such ships were captured a diplomatic problem could arise, but Spain and Morocco tried to preserve their good relations by acting prudently. In 1772 Captain Sidi al-Arbi Mistiri asked the admiral of Cartagena to "free fourteen slaves from Salé seized out of Algerian corsairs," insisting that he was

making this request privately; since you are also Admiral of the Fleet by rank ... and therefore at the same level as Mr. Reggio, you need not bring up this matter with His Moroccan Majesty. ${ }^{23}$

21 “...varias embarcaciones marroquinas cuyos comandantes han faltado a su[s] obligaciones en un punto tan esencial como ocultar en nuestro[s] Puertos que hubieran tocado en el de Argel con gran riesgo de la Salud publica de estos Reynos": draft from El Pardo to T. Bremond, 1 February 1773, AHN, Estado, leg. 3412.

22 J.M. González Salmón to Count Floridablanca, Tangier, 8 October 1781, AHN, Estado, leg. 4314 .

23 “...hizo la petición privativamente por si con respecto a ser también Almirante de la Mar ... y que por esta casualidad de igual en graduación con el Sr. Reggio sin tocar en ello asunto a S.M.M": T. Bremond to Marquis of Grimaldi, Larache, 15 November 1772, AHN, Estado, leg. 4312. 
Other problems were provoked by the poor conduct of Algerian captains and sailors serving on Moroccan corsair ships. After an unpleasant incident in which "an Algerian captain carried off a Christian from Cádiz," the sultan even forbade his ships from entering Spanish ports "so that such a thing will not happen again."24

Some episodes were not lacking in humor. Three Tunisians shipwrecked near Orihuela claimed to be Moroccans who had escaped from Malta, and were entrusted to the captain of a Moroccan frigate in Cartagena; but later it was learned that they were actually escaped slaves from Majorca. ${ }^{25}$

The best way to illustrate the range of situations that arose will be to describe the behavior of certain Moroccan captains in Spanish ports.

\subsubsection{Incidents Provoked by Captains}

We have seen how treaties stipulated that Moroccan warships in Spanish ports should receive all necessary attentions for the ships themselves and for their crews, and that these services were to be paid for. ${ }^{26}$ But occasionally in the years following the Treaty of 1767 supplies of "refreshments" and some repairs were offered free of charge.

This leniency gave rise to a number of abuses. Some Moroccan captains tried to have all the food and supplies for their crews, as well as major repairs to their ships and new rigging, sails, and equipment, underwritten by Spain. In this they took for granted that the early cases of free supplies and repairs - a courtesy granted after the Treat of 1767 was signed - gave Moroccan corsair ships the right to the same services in perpetuity. While they argued that Spanish warships received the same consideration in Moroccan ports, in fact services there were much more limited: in a few cases there were offers of free "refreshments" and some materials for making repairs. ${ }^{27}$ It is possible that most

24 T. Bremond to the sultan, 19 November 1772, AHN, Estado, leg. 4312.

25 Draft from El Pardo to José Boltas, 20 March 1780, AHN, Estado, 4313.

26 Moroccan ships in Cádiz in 1780 and 1786 paid for their repairs in cash: Lourido Díaz, Marruecos en la segunda mitad, 102-04.

27 Free refreshments were normally offered to Spanish warships that docked in Moroccan ports on official missions, for instance during Jorge Juan's embassy in 1767: Rodríguez Casado, Jorge Juan en la Corte, 10; Sánchez Carrión, La embajada inacabada de Jorge Juan, 148-49. The war frigate Santa Rosa under Captain Federico Gravina, which brought thirtyfive released Algerian slaves from Cádiz to the governor of Tangier, also received refreshments: J. M. González Salmón to Count Floridablanca, Tangier, 14 February 1788, AHN, Estado, leg. 4321. But it is hard to find evidence of repairs to damaged Spanish vessels. One instance (though of a merchant ship) was a Spanish ship that had loaded wheat in Casablanca and was forced into Mogador by wind. The sultan ordered the city's governor "to gather master workmen to repair it in any way it needs, drawing on the warehouses for the necessary equipment; and its captain and sailors should be provisioned, and every 
Spanish warships that docked in Morocco - almost always on official missions, not in mere stopovers - received "refreshments," but only very rarely were they repaired or given naval supplies, since Morocco could not afford it. Nonetheless, in 1789 the sultan ordered that

For all the Spanish ships that enter our ports, if they lack cables or sails, we have arranged to provide them. And the same shall be done for ships that come from the Canaries to Casablanca or Mogador, allowing them whatever refreshments they wish free of duties. ${ }^{28}$

The vice consul reported the offer to the Secretary of State, but insisting that the materials received would not be free of charge but rather "free of duties."29 In contrast, Moroccan captains most often entered Spanish ports, especially Cádiz and Cartagena, expecting free repairs for their vessels: some asked it as a special favor, while others made it an insolent demand.

Most of the incidents described here therefore involve Moroccans: their country was closer to Spain than Algeria, Tunis, or Tripoli and also provides most of our documentation. Though problems provoked by Moroccan captains and corsairs in Spanish ports were not many, some of them caused considerable tension. Because both countries feared that such conflicts would threaten their alliance, which they considered a crucial one, both tried to limit their effects as much as possible.

7.1.1.1 Captain of the Frigate Mahoma (1769)

This frigate was repaired in Cartagena during the first half of 1769 . The work cost the Royal Treasury a large sum, and the crew behaved badly: an official letter spoke of "the disagreeable acts performed by its crew; communications with that sovereign about these matters and the replies with which he satisfied us."30

other thing offered, until the ship sails at the time it chooses": translated letter from the sultan to J.M. González Salmón, 22 August 1786, AHN, Estado, leg. 4319.

28 Translated letter from the sultan, 15 October 1789. Alcayde Driss wrote to the European consuls in Tangier lauding the sultan's generosity toward Spain, "of which there is no other example in the annals of this country." He added that everything would be provided for free, including hemp, pitch, decking, and wood for construction: AHN, Estado, leg. 4321.

29 A. González Salmón to Count Floridablanca, Tangier, 14 November 1789, AHN, Estado, leg. 4321.

30 Draft letter from Madrid to Tomás Bremond, 10 April 1770, AHN, Estado, leg. 5818. 
Tomás Bremond wrote to the sultan about the repairs, in which "materials lacking in the Mahoma were supplied"; he noted that in the process "the best carpenter lost his life (which was the most regrettable thing)." He also begged "that you no longer send your ships to be repaired in the shipyards of the king my master, because all their workmen are busy with his own ships." He requested that the sultan's captains no longer dock in Spanish ports "unless the weather or some accident forces them to seek shelter."31

\subsubsection{Aly Aguet (1769-1770)}

In 1769 a Moroccan warship, the packet-boat ElSenó under Captain Aly Aguet, ${ }^{32}$ docked at Cartagena, where it remained from 4 to 22 December.There it was provided with timbers, oars, gun carriages, wedges, rigging, cables, pulleys, sails, lengths of cloth, pitch, grease and tallow, nails, metal, iron goods, lanterns, barrels, hemp articles, clay, and hides, to a total value of 43,709 reales de vellón and 23 maravedís. The men who worked to repair the ship - carpenters, caulkers, sawyers, coopers, seamen, and others - were paid 6,447 reales and 26 maravedís. By order of the supply officer they were issued bread, salt fish, raisins, rice, lard, oil, vegetables, coffee, sheep, salt, tobacco, charcoal, soap, and tallow candles, to a value of 10,435 reales de vellón and 23 maravedís, plus other foodstuffs and items for twenty-one days at sea such as candleholders, lamps, vinegar, and sewing needles that cost 8,376 reales and 32 maravedís. Rations of biscuit, water, and six casks added 3,111 reales and 26 maravedís, for a grand total of 72,081 reales and 8 maravedís, a sum that was reported to the sultan of Morocco. ${ }^{33}$

In early January 1770 Captain Aly Aguet returned to Cartagena proposing to winter there for three months, "requesting that he be issued the necessary victuals until the coming month of March, when he plans to sail." ${ }^{34}$ Port authorities complained repeatedly of the conduct of the captain and his crew. Most seriously, the Moroccans took in five soldiers from city regiments who

31 Tomás Bremond to the king of Morocco, Larache, 3 May 1770, AHN, Estado, leg. $5^{818}$.

32 He also appears as Aly Auguet and Sedy [Sidi] Aly Ahoüad.

33 The ship was also provided with 120 quintales of wood from the hull of the frigate Mahoma. The victuals and other products were supplied by a local merchant named Juan Balart: "Relacion del costo de la Real Hacienda en el paquebote El Senó desde 4 a 22 diciembre de 1769 ." There are also notes on payments signed by Manuel de la Riva, Cartagena, 22 and 30 December 1769 and 5 January 1770. The total sum appears in a report from Julián de Arriaga to Marquis of Grimaldi, Palacio, 9 January 1770. See "Expediente paquebote marroquí El Senó. Sobre su habilitación y sobre que no se compondrán en nuestros arsenales más embarcaciones de guerra marroquíes," AHN, Estado, leg. 5818.

Julián de Arriaga to Marquis of Grimaldi, Palacio, 19 January 1770, AHN, Estado, leg. 5818. 
had deserted, renounced Christianity, and converted to Islam; the deed had been facilitated "by Moors among the crew, who disembarked, tempted them, and seduced them to this outrage." Further, the ship's sailors had tried to help a female Muslim slave to escape:

In the neighborhood called La Concepción, outside the city walls, there was word that a Moorish woman, a private individual's slave, was escaping with the help of two Moors. Officers and residents of that area gave chase and managed to apprehend her, but not the Moors; those climbed a nearby hill and then descended to the port which was behind it, next to the slip where the packet-boat was docked. I immediately remanded the Moorish woman to prison, and when I threatened her with punishment to make her reveal the identity of the Moors who persuaded her to flee and protected her, she stated that they belonged to the crew of the aforesaid warship; she gave some details of their faces and clothing but did not know their names. ${ }^{35}$

The governor continued his account of the Moroccans' bad behavior and asked for guidance about how to proceed, in view of the

disturbances they are causing in this port; and no measures or orders I have given are enough to avoid them. While the garrison and the citizenry behave with perfect correctness and offer them not the slightest insult or vexation, from the Moors we find continual infractions and causes for unpleasantness; therefore I sent the sergeant-major of the port to reprove the captain and explain to him how irregular these actions are. As a result the two Moors who had tempted the female slave had to disembark and confront her, and she confirmed that they were the ones who had persuaded and assisted her, although they denied it. Once they were back on board the captain promised to keep them confined and take them as

35 "[Se] advirtió en el Barrio que nombran de la Concepcion extramuros de esta Ciudad, que una Mora esclava de un particular hacia fuga, amparada de dos Moros, y dándosele alcanze por los Diputados, y gente de aquella Poblacion, se logró aprenderla, y no a los Moros, porque se subieron a un Monte próximo para dexarse vajar al embarcadero, que hay à su espalda, inmediato al parage en que está fondeado el Paquevote. En seguida hize reducir à prisión la mora, y conminándola con castigos para que declarase quienes eran los Moros que persuadían, y abrigaban su huida, manifestó que eran de los de la Tripulacion del referido buque, dando algunas señas de sus rostros, y trages aunque ignoraba sus nombres": Carlos Reggio to Marquis of Grimaldi, Cartagena, 24 March 1770, AHN, Estado, leg. 5818 . 
prisoners to his Emperor so that he could punish them properly; but if repeated instances of these insults against the sacred immunity of our territory lead to further consequences beside the ones already suffered, [it will be] seriously prejudicial to the State. ${ }^{36}$

The Secretariat of State agreed with the governor that the Moroccans' conduct was deplorable and that they were "repaying very badly the great attention and condescension we have shown toward the Moors." The Madrid authorities saw no reason why the packet-boat should continue in port "costing the Royal Treasury the expense we all are aware of," so they conveyed the king's order to "let the captain know, politely and courteously, that from the date of receipt of this letter his crew will no longer be given any supplies as they have been up to now." The deserters must be turned over in the hope that "with this act they will leave port, and the captain should be told that His Majesty is much displeased with the conduct of the crew and will write to the sultan of Morocco."37

Carlos Reggio conveyed the king's displeasure to the captain, insisting that "because of the coarseness of these people" they would have to embark "to relieve me of the anxiety I have been caused." He had kept the ship in isolation by posting troops around the dock and forbidding any boats to reach it, but to little avail on account of

the continual distressing incidents that the prolonged presence of these men here has caused. I have had to employ whatever measures prudence can suggest to endure such irregular conduct. For while I flatter myself that I have maintained strict control over the garrison and the residents so that they cause the Moors not the least vexation, the latter with their drunkenness and excesses have been ready to commit all manner of

$36 \quad$ “...inquietudes que están originando en esta Plaza, sin bastar las providencias, y ordenes que tengo dadas para evitarlas, pues aunque por parte de la Guarnicion, y Vecindario, se observan exactissimamente sin producirles el menor insulto, ni vexacion; por la de los Moros se advierte una continuada infraccion, y motivos de disgustos, embié a el Sargento Mayor de la Plaza, á que recombiniere al Arraez, haciendole ver la irregularidad de estos procedimientos, de que resultó hacer vajar à tierra los dos Moros seductores, para que se careasen con la Esclava, la qual, aunque ellos negaron, ratificó ser los que la persuadían, y auxiliaron; y sin embargo, de que regresados a bordo, me ha ofrecido el Arraez mantenerlos asegurados, y llevarlos presos a su Emperador, para que les imponga el Castigo correspondiente, como la repetida ocurrencia de estos insultos, hechos contra la Sagrada inmunidad del Territorio, dé margen à otras conseqüencias, además de las experimentadas hasta aquí, gravemente perjudiciales al Estado": Carlos Reggio to Marquis of Grimaldi, Cartagena, 24 March 1770, AHN, Estado, leg. 5818.

Draft to Carlos Reggio, El Pardo, 2 April 1770, AHN, Estado, leg. 5818. 
insults, which I have prevented only through the greatest vigilance by not confronting them until they could not be disguised or tolerated any more.

He added that he had sent the sergeant-major of the port and the officers of the deserters' regiments to demand they be given up, but the soldiers had "declared openly and continuously that they abjured our holy faith and staunchly called themselves Moors." The Moroccan captain refused to surrender them, under the terms of the treaties, "because they persisted in the Mohammedan faith," so the governor decided to impose consequences: "I will tell the captain that he will be given nothing for the sustenance of his crew." ${ }^{38}$ The ship finally sailed on 4 April, but was forced back into port by a southwest wind; it left for good only ten days later, with the five deserters, "who remained constant in their determination," on board. ${ }^{39}$

After the Moroccans' departure an accounting was made of what their stay in port had cost: food and supplies came to 38,556 reales and 12 maravedís between 17 January and 3 April 1770, to which were added 9,447 reales and 32 maravedís for twenty-one days of sailing. ${ }^{40}$ The captain and officers were allowed supplies to a value of 3,527 reales and 6 maravedís for seven days at sea. By order of the supply officer the ship was issued rations of biscuit, water, and packaged goods (4,073 reales and 15 maravedís) as well as rigging, canvas, and gangplanks (1,707 reales and 7 maravedís). An interesting group of items were medical and sanitary supplies (syrups, salts, unguents, plasters, other medicines, utensils, packaged goods, and hospital stays for sick crewmen at a rate of four reales per day apiece), which added up to 25,966 reales and 23 maravedís. Crew members admitted to hospital were Jafar son of Eferrar (aged fifty-four), Majamet son of Belerri or Velerri (thirty-five), Sidi Majamet Benllas son of Majamet (thirty-six), Majamet Egueri son of Belerri (twelve), Abadala Megeyer

38 “...las continuas, y embarazosas ocurrencias que ha originado la dilatada permanencia aquí de esos hombres, que ha sido preciso valerme de quantos medios puede sugerir la prudencia para sobrellevar tan irregular conducta, pues al paso que puedo lisonjearme de haver tenido la guarnición, y vecindario en los términos mas ceñidos à no producir la menor vejación à los moros, estos con sus embriaguezes y excesos han caminado siempre dispuestos à cometer todo genero de insultos, que he procurado à costa de la mayor vigilancia precaver en lo posible omitiendo representarlos, hasta que no cabiendo en el disimulo, y tolerancia los hechos.... [I]ntimaré al Arraez en que nada se le ha de subministrar para la manutención de su tripulación": Carlos Reggio to Marquis of Grimaldi, Cartagena, 3 April 1770, AHN, Estado, leg. 5818.

39 Carlos Reggio to Marquis of Grimaldi, 7 and 14 April 1770, AHN, Estado, leg. 5818.

40 The foodstuffs were provided by the local merchant Juan Balart. Two reports of spending were signed by Manuel de la Riva on 28 April 1770 . Of the total, 86 o reales were given to Captain Muley Abdelcader at a rate of twenty reales a day: AHN, Estado, leg. 5818 . 
son of Fier or Gier (eighteen), and Mohamet Belbeli son of Fier (twelve) $\cdot^{41}$ The total of all these accounts was 83,946 reales and 27 maravedís. ${ }^{42}$ After adding in the 72,081 reales and 8 maravedís from December 1769 , the grand total rose to 156,028 reales and 28 maravedís. ${ }^{43}$

The Secretariat of State also expressed its disapproval to the Spanish consul in Morocco, Tomás Bremond, noting that the packet-boat had appeared in Cartagena with no apparent motive beside "the desire of its commander" but had still been treated with "the greatest consideration." The captain's arrogance, especially his assumption that he could winter in Cartagena, was excessive:

This vessel entered Cartagena without having been forced there by the wind or having suffered any damage, and its commander declared that he would remain there all winter so as not to expose himself to the sea, while the whole crew would be maintained as before at His Majesty's expense. It was not normal to have presented such an extravagant request; but through an excess of consideration and to give one more proof of cordiality to the king of Morocco, the king became involved. It would be hoped that the Moors would reciprocate such humane and friendly treatment at least with proper conduct, without giving us much reason for complaints and distress, but just the opposite has occurred, as you must be aware.

Further, Captain Aly Aguet had contravened his orders from the sultan:

The king is convinced that this conduct is entirely opposed to the King of Morocco's intent, but it is very painful to His Majesty to see it repeated so often with severe prejudice to his royal service and that of his own subjects.

Bremond was therefore instructed to write at once to al-Gazzal, Samuel Sumbel, and especially the Moroccan sovereign to inform them "of everything in detail," making clear that

41 "Relacion de los gastos ocasionados por los géneros suministrados al paquebote El Senó desde 17 enero hasta 3 de abril, mandado por el gobernador de Sale, Ali Auguet," and accounts signed by Manuel de la Riva, Cartagena, 28 April 1770, AHN, Estado, leg. 5818.

42 Accounts signed by Manuel de la Riva, Cartagena, 28 April 1770, AHN, Estado, leg. 5818.

43 Julián de Arriaga to Marquis of Grimaldi in Aranjuez, 1 May 1770, AHN, Estado, leg. 5818. 
in spite of the affection and friendship that the king professes for that sovereign, it is wholly impossible for him to agree to repair or rebuild any more warships in his shipyards, as has been done with these two. First, because these costs are too high, and this results in a scarcity of materials to be used for our own vessels; and second (and more important), because it will bring His Majesty unhappiness and complaints from other princes and powers who are his friends and to whom he does not extend such favors.

Bremond was to ask the sultan to order his captains "not to attempt to enter our ports expecting to request any repairs of their vessels that they wish, because these will not be performed." In case of accidents or storms, however, "they will find all the help that is due to the intimate friendship existing between the two sovereigns." A postscript noted that the packet-boat was prepared "to sail with the first favorable wind, without any force on our part aside from the complaints we have presented to them." 44

In May 1770 Bremond wrote to the sultan explaining Spain's unhappiness over the affair of the frigate Mahoma in 1769, about which he had complained on 6 August of that year. Samuel Sumbel had assured him that the sultan "did not plan to send any of his corsair [ships] to be repaired in Spain, nor did he need to do so," and yet Captain Aly Aguet had arrived in Cartagena in

44 "[S]e restituyó a Cartagena dicha embarcación sin estar forzada de los vientos ni haber recibido descalabro alguno, y su comandante dijo que pensaba quedarse allí todo el Ynbierno por no exponerse al Mar, y que se debía mantener como antes a toda la tripulación a quenta de S.M. No parecía regular haber executado tan descabellada solicitud; pero por exceso de atención y por dar esta prueba mas de cordialidad al Rey de Marruecos, vino el Rey en ello. Debia esperarse que a un trato tan humano y amistoso corresponderían los Moros de aquella embarcación a lo menos con un proceder regular, no dándonos muchos motibos de quejas y de disgustos. Pero ha sido tan al contrario como podrá vm. Reconocer. ... [E]stá el Rey muy seguro de que estos procedimientos son enteramente opuestos a las intenciones del Rey de Marruecos, pero sin embargo es mui sensible a S.M. verlos tan repetidos con grave perjuicio a su real servicio y de sus propios vasallos. ... [A] pesar del afecto y amistad que el Rey profesa a ese Soberano le es absolutamente imposible volver a tener la condescendencia de componer o renovar en sus arsenales ninguna otra embarcaciones [sic] de guerra, como ha hecho con estas dos; lo primero porque son demasiado crecidos estos gastos y se escasean por este medio para nuestros propios vaxeles los materiales que se emplean en ellos; y lo segundo (y mas principal) porque se atraheria S.M. el disgusto y quejas de los demás Príncipes sus amigos y Potencias con quienes no hace ni hará tal demostración. ... [debía] hacerse a la vela con el primer viento favorable, sin que se les obligase a ello, y solo por las quejas que les hemos dado." The first mate and pilot was Sedi Reis Homar: Madrid to Tomás Bremond, 10 April 1770, AHN, Estado, leg. 5818 . 
December "without any need at all nor having been forced by the weather, and was received with the greatest pleasure and attention." The repairs, provisions, and victuals provided cost the Royal Treasury 3,604 pesos fuertes. Aly Aguet then went to sea, but returned to Cartagena and was again well received by express order of the king, who, "to give Your Majesty proof of his esteem, consented to it even though he does not do the same for any other prince among his allies."

On his sovereign's orders Bremond therefore told the sultan "that the captain has repaid us very badly, allowing his seamen to influence soldiers of that city with promises so that they boarded Your Majesty's ship, to which they also took a Moorish woman." In consequence the king of Spain, "in spite of the true friendship he professes for Your Majesty," was asking him to send no more vessels to be repaired in Spanish ports and to instruct his captains not to enter them unless "the weather or some accident forces them to take shelter."45

Bremond reported back to the Marquis of Grimaldi about his letters to the sultan, al-Gazzal, and Sumbel; he had asked the latter two that in the event the sultan ordered their letters read in his presence "they do so in such gentle and friendly terms that he be convinced without becoming disturbed." ${ }^{\prime 6}$ After an interval of silence Bremond received a missive from the director of the hospice in Marrakesh, informing him of the sultan's satisfaction "with the good treatment that Captain Aly Aguet received, [but] with no reference to the principal matter, that he should not send his ships to be repaired in Spain." ${ }^{.7}$

Finally the Alawite monarch responded (in French) through his secretary Samuel Sumbel. He expressed pleasure at the fact that "his ships may enter ports where Muslims are esteemed as much as Spaniards," but he had ordered his captains not to enter Spanish ports. He excused Aly Aguet because he was not a navy captain, "having had no experience at sea, having been only governor of a port when he entered Cartagena," but nonetheless stripped him of his title: "he is demoted from his post as captain for having stayed in Cartagena, which is the cause of this misunderstanding."

The letter noted that Spanish warships were welcome in Moroccan ports, and repeated the invitation to have them supplied there with food, equipment, and armaments without charge. The Spanish should know that if their ships had incurred costs in such cases, the sultan would never have

45 T. Bremond to the king of Morocco, Larache, 3 May 1770, AHN, Estado, leg. 5818.

46 T. Bremond to Marquis of Grimaldi, Larache, 10 May 1770, AHN, Estado, leg. 5818.

47 Bremond promised to press the point with al-Gazzal and Sumbel: T. Bremond to Marquis of Grimaldi, Larache, 8 June 1770, AHN, Estado, leg. 5818. 
complained to their monarch about it. As for deserters, Morocco would return any who reached its shores unless they had converted to Islam, as had been agreed by both countries: "on becoming Muslims, the law protects them; only if one who has come from your side remains a Christian would we send him back." Finally, he understood the Spanish king's annoyance when "some Moors in the crew drank liquors or [did] other things that could produce a melée between the crewmen and subjects of His Catholic Majesty," and as a result the sultan would forbid Moroccan corsairs to enter Spanish ports, even in search of water. ${ }^{48}$

The Secretariat of State replied promptly, also in French, expressing its and the king's surprise at the sultan's words. It insisted that the Spanish monarch had always intended to welcome Moroccan warships into Spanish ports:

We have the honor of assuring you that [forbidding them] has never been the king's intent, rather the contrary: orders have always been issued to admit them with cordiality and to help them in everything they might need. And I must add that the king of Morocco should be convinced of this fact by the repeated experiences of his warships in Spanish ports.

Still, some Moroccan captains made unreasonable demands: without

the slightest accident at sea they demanded extensive rebuilding and expected poorly built old ships to be suddenly transformed into well-built new ones, something that is impossible.

Captains like these, instead of pursuing corsair warfare in their sovereign's interest, wanted to spend two or three months in Spanish ports "demanding, often with threats, not only necessary help but everything that came into their minds." When their crewmen went on land they committed all kinds of offenses that could harm the good relations between the two countries. And as for deserters, it seemed that crews of Moroccan ships persuaded them to convert through sheer "caprice."

Finally, Spain's missive concluded, the Spanish monarch would admit Moroccan warships to Spanish ports with "the greatest cordiality, to render them all possible help and services (as has been done up to now)." Necessary repairs would also be made as long as they arose from accidents at sea. But the sultan was asked to reflect on whether captains should spend months in a Spanish 
port without any need, and demand expensive repairs; if that were so, Spain would have to offer the same favors to ships of its other allies. In a final tactful note, it was suggested that the sultan's misunderstanding might have arisen from an inaccurate translation. ${ }^{49}$

\subsubsection{Ysmain Tunesi (1772)}

After Captain Ysmain Tunesi of the corsair xebec Teulen docked at Cartagena in October 1772, he either did not wish or was not able to pay for the food he was given and refused to sign a receipt. Tomás Bremond related that the captain had arrived

with his ship badly damaged, declaring that he wished to winter there. He asked the governor to supply everything he would need, and that was agreed to on condition that he provide a receipt. This he did not accept, though it was explained to him that it was necessary for unloading and for giving an accurate account to the officials. And also because the king my master had ordered the governor to demand it, after the latter had notified him of the captain's arrival and the fact that he would not give a receipt. ${ }^{50}$

The consul explained to the Moroccan sultan that Spain received foreign corsair ships only for the time needed to rescue or repair them, and that he should therefore order the captain

49 “...l'honneur de vous assurer que ca n'a jamais eté l'intention du Roy, et qu'au contraire les ordres ont eté constantemente donnés pour les y admitir avec cordialité, pour les secourir en tout ce dont ils pourraient avoir besoin et je dois ajouter que le Roi de Marroch doit etre convaincu de cette verité par l'experience reiteré que ses vaisseaux de guerr[e] en ont fait dans les Ports d'Espagne. ... [après] le moindre echec sur mer ils exigaient des reparations enormes, et pretendoient que des vieux vaisseaux de mauvaise construction fussent changés subitement en vaisseaux neufs et bien construits, ce qui etoi[t] imposible": Aranjuez to Sumbel, draft specifying that the letter should go to both alGazzal and Bremond, 28 June 1770, AHN, Estado, leg. 5818.

$5^{\circ}$ “...con su embarcación rota, y decir era de su gusto pasar allí el Ymbierno, pidió al Governador le diera todo quanto necesitara, lo que efectivamente le concedió a condición de que le entregara Rezivo, lo qual no quiso admitir, no obstante que le manifestó era preciso para descargo y formalidad de la cuenta de los Dependientes, y porque también lo ordenaba asi el Rey mi Amo a dicho Governador en consequencia del aviso que le pasó del arribo del Harraez, y de que se negaba a dar el Rezivo": T. Bremond to Marquis of Grimaldi, Larache, 5 December 1772. Al-Gazzal accepted the consul's version of events: alGazzal to T. Bremond, 23 March 1773, AHN, Estado, leg. 3412. 
to depart as soon as he has finished the repairs and not remain voluntarily for no reason, so as to avoid any error that might occur either on our side or on the captain's. ${ }^{51}$

Tunesi wrote al-Gazzal two letters of his own. In the first he accused the military governor of Cartagena of "not giving him anything to eat, so that he was reduced to selling his clothes in order to support himself," but in the second "he heaped a thousand praises on the help that that governor had given him." Al-Gazzal, by arrangement with the Spanish consul, decided to send the sultan only the second letter "and to suppress the other one to avoid angering him."52 But the sultan learned of the captain's conduct and wrote him a stern letter, accusing him of disobeying orders:

What are you doing in Cartagena? The only reason for your lingering there is your lack of ability: the xebec needs no more than four or five days' work. If you wanted to enter some port you would have done better to go to Algiers. I order that on receiving my letter you leave Cartagena and go to Tetouan; if you delay your departure I will punish you severely. I will compensate the Spaniards for everything they spend on repairing the xebec. ${ }^{53}$

$51 \quad$ “...que se retire luego que se acabe de componer, y no se quede allí voluntariamente sin motivo, para evitar alguna falta que pueda suceder por nuestra parte o por la del Harraez": T. Bremond to the Moroccan sultan, 19 November 1772, AHN, Estado, leg. 3412.

52 T. Bremond to the emperor of Morocco, Larache, 19 November 1772. Bremond was satisfied that the affair "did not cause his Moroccan Majesty to be angry with us," and hoped the monarch would order the governor of Tetouan "to send in all haste to Cádiz one of the principal men of that city, who after traveling to Cartagena by land will force Ysmain to leave at once": T. Bremond to Marquis of Grimaldi, Larache, 14 December 1772, AHN, Estado, leg. 3412.

53 "Que hazes en Cartaxena tu detención ahí solo estriva en tu poca havilidad: el travajo que nezesita el Xaveque no es mas que de quatro a cinco días. Si querias entrar en algun Puerto, pudieras haver ido a Argel, lo qual huviera sido mejor. Te mando, que en vista de esta mi Carta salgas de Cartaxena, y te vayas a Tetuan: si te tardaras en salir de ahí te daré un gran castigo. Todo lo que gastaren los Españoles en componer el Xaveque se lo satisfaré": Letter from Sidi Mohammed Ben Abdalá to the captain, 4 December 1772. A second letter of the same date to the Spanish consul is equally harsh: "To this letter I attach another in Arabic that you will send to Captain Ismán in Cartagena, to whose governor you will write [saying] that the repair of the xebec takes only three or four days and that as soon as the workmen finish repairing it they force him to depart as soon as possible, without letting him stay even an hour. But if the captain refuses, the governor should expel him by force": AHN, Estado, leg. 3412. 
The affair continued to be mentioned in Spanish diplomatic correspondence until March of 1773 , though it was handled with discretion to avoid negative repercussions. ${ }^{54}$

\subsubsection{Captains Mohamet Cherif and Abu-l-Qasim (1772)}

These two captains set out on a cruise in the summer of 1772 . Their misconduct brought them into the presence of the sultan who, deeply displeased, accused them of being "disloyal in their service; for they spend the campaign period going from port to port without applying the diligence they owe to the trust, salary, and high rank they hold." He placed Mohamet Cherif "in chains as a punishment for having seized a Maltese sailor in Cádiz."

Abu-l-Qasim's luck was even worse:55 he had returned from Cádiz with "a dozen oars for Muley Arzit that the navy's supply officer had given him, claiming that he took them for that reason." We do not know exactly what his offense was, but his punishment was severe: "He had hardly begun to speak when by order of the prince he was interrupted with the words 'You lie!. He was handed over to be beaten, such that they tore out his teeth and his upper lip." The sultan accused them of "spend[ing] the period of the [corsair] campaign going from one port to another without taking heed of our trust, their salary, and the high rank they enjoy."

A group of drunken Moroccan sailors who had profaned a church in Cádiz were also dealt with harshly:

Learning that seven sailors had entered irreverently into a church in Spain, one of them smoking a pipe - and he drew a knife on the sacristan who was defending it - he ordered all seven to have their arms broken. And dressed in dogskins, with caps of the same material adorned with tinkling bells around their heads, they were paraded through the city. Though they were sentenced to be hanged

54 The captain was reluctant to leave the safety of Cartagena, fearing hostility from Dutch warships whose country was an enemy of Morocco at the time: Carlos Reggio, governor of Cartagena, to Marquis of Grimaldi, 12 January 1773. Letter from the palace of El Pardo to C. Reggio, 19 January 1773. The xebec did not sail until 26 January 1773, having accumulated costs of 22,939 reales de vellón and 19 maravedís: C. Reggio to Marquis of Grimaldi, 23 and 26 January 1773. Julián Arriaga to Marquis of Grimaldi, 3 February 1773. Crew members who had fallen ill were treated in the local hospital, and the ship was also given "fresh food for thirty days": T. Bremond to Marquis of Grimaldi, Larache, 24 March 1773, AHN, Estado, leg. 3412.

He also appears as Cassen. 
in La Leonera the sentence was commuted to prison, where they remain. ${ }^{56}$

\subsubsection{Mohamed al-Farache (1772)}

He was another captain ${ }^{57}$ who drew the sultan's ire in 1772 , accused of a lack of zeal in his corsair activity. On hearing of the punishments meted out to Mohamet Cherif and Abu-l-Qasim "he took refuge with a holy man."58 But in later years he occupied important government positions in Morocco, and the Spanish consul in Tangier considered him one of the fiercest partisans of the English during the 1779-1783 war: "Farasch is one of the most impassioned [friends] of the enemy, and nothing could persuade him to come over to our side." ${ }^{59}$ In $1782-1783$ the consul in Tangier and the governors of Málaga and Melilla helped him to recover artillery pieces of the sultan's that had been left behind in the presidio after the war of $1774-1775 .{ }^{60}$

\subsubsection{Abdalá al-Asseri (1774)}

In April 1774 a twenty-gun Moroccan frigate with a crew of seventy-two, commanded by Captain Sidi Abdalá el Asseri, was wrecked on the beach of La Atunara in La Línea de la Concepción, next to Gibraltar. The military governor of the Gibraltar region, Agustín de Mendoza, reported that all possible help had been offered:

The people saved themselves by leaping into the sea but the ship will not be so fortunate, for it has received the full force of the waves and is buried deep in the sand. Still, it is being lightened of its artillery and other cargo to see if it will float; for which, and for anything else they may need, I have promised its officers my help, and the Minister of the Navy said the same

$5^{6}$ "Savedor de que siete Marineros entraron con irreverencia en una Yglesia de España, fumando uno de ellos la pipa, y que sacó el Cuchillo contra el Sacristan que la defendía, hizo que a todos siete les rompieran los brazos, y que vestidos de pieles de perros, bonete de lo mismo con cascabeles pendientes alrededor de la cabeza los paseasen por la ciudad, y aun que fueron condenados a que después los colgasen en la Leonera, se revocó conmutandolo en prisión, en la que están": T. Bremond to Marquis of Grimaldi, Larache, 30 January 1773, AHN, Estado, leg. 3412.

57 Also called al-Farasch.

$5^{8}$ T. Bremond to Marquis of Grimaldi, Larache, 30 January 1773, AHN, Estado, leg. 4312.

59 In 1781 al-Farache was involved in some way with the provision of supplies to Gibraltar:J.M. González Salmón to Admiral Antonio Barceló of the Spanish navy, Tangier, 7 January 1781, AHN, Estado, leg. 4314.

6o See the introduction to this section. 
when I informed them of the disaster. But since we do not have the proper equipment and tools here they will have to be brought from Gibraltar, which I will permit them to do. ${ }^{61}$

The vice consul in Tangier, Francisco Pacheco, informed Secretary of State Grimaldi that the sultan, through the governor of Tangier, had ordered him to Spain to see to the crew and cargo of the frigate, "which a furious squall had hurled against one of the batteries of the Campo de Gibraltar." The sultan's letter, penned in French by Samuel Sumbel, declared that "the sultan will be pleased if on receipt of the present you embark in the first ship to go to the spot where his vessel was wrecked." ${ }^{2}$ Pacheco set out for Gibraltar at once. ${ }^{63}$

It was reported from La Línea that salvage work on the frigate had already begun:

Work is underway to determine if it can be recovered, for which, since the required tools and experts do not exist here, they have been requested from officials in Gibraltar; and they have come from there with permission from that governor and from me. ${ }^{64}$

61 “...haviendose salvado la Gente arrojándose al Agua, pero no espera logre igual suerte la Nave, por lo que ha padecido con el ímpetu de las Olas, y lo mui enterrada que ha quedado en las Arenas, aunque sin embargo se esta aligerando de la Artilleria, y demas equipaje, para ver si puede sacarse a salvamento, á cuyo fin, como para qualquier otra cosa que se les ofresca, he prometido á los oficiales de ella mis auxilios, y lo propio ha practicado este Ministro de Marina, á quien avisé luego esta desgracia; pero por no haver aquí los Aparejos, y otros útiles necesarios será presiso los traigan de Gibraltar, lo que les permitiré": Agustín de Mendoza Pacheco, Military governor of the Gibraltar region, also reported a great storm on 22 to 26 April: letter to Marquis of Grimaldi, Campo de Gibraltar, 28 April 1774, AHN, Estado, leg. 5802.

62 Francisco Pacheco to Marquis of Grimaldi, Tarifa, 8 May 1774. Sumbel stated (erroneously) that the frigate "had struck the coast of Spain at Estepona" (which is in Málaga): S. Sumbel to Francisco Pacheco, 30 April 1774. There is also a copy of the letter that the governor of Tangier sent to Agustín de Mendoza, dated 7 May 1774, instructing that the crew and effects of the frigate be turned over to Pacheco: AHN, Estado, leg. 5802.

63 He arrived on 10 May with the governor of Tangier's letter: Agustín de Mendoza to Marquis of Grimaldi, Campo de Gibraltar, 12 May 1774. For Pacheco's passage from Tangier to Algeciras see Tomás Bremond to Marquis of Grimaldi, Salé, 30 May 1774. On leaving Tangier Pacheco told Bremond that he was leaving the vice consulate to Juan Manuel González Salmón: F. Pacheco to Tomás Bremond, Tangier, 6 May 1774, AHN, Estado, leg. $5^{802}$.

64 “[S]e están ejecutando las faenas para provar, si puede salvarse, a cuyo fin, no habiendo aquí los útiles ni Practicos correspondientes, los han solicitado a Gibraltar los oficiales de ella, de donde han venido, con permiso de aquel Governador y el mio": Agustín de Mendoza Pacheco to Marquis of Grimaldi, Campo de Gibraltar, 2 May 1774, AHN, Estado, leg. 5802 . 
Problems began to arise, of which Grimaldi was informed immediately: "The captain of a Moroccan frigate that was stranded near San Roque will not accept the help that we offered him free of charge." ${ }^{25}$ The commissioner of the navy had asked the captain "to request and acknowledge the items with a reasonable accounting," which Asseri refused to do; instead he decided to seek aid in Gibraltar,

since the ship is much closer to Gibraltar where the proper equipment and tools are located, which are lacking here. The captain believed it better to appeal to the English, and has not wished to accept any help from our people, although the English governor had agreed with the military governor of the San Roque region before offering to do the work. ${ }^{66}$

Consul Tomás Bremond was alerted "in case the captain should present a complaint." In that case Bremond should inform the sultan that

the appropriate offers were made on our side, that in fact the necessary equipment and tools were not found there and the distance was greater, and that the formality of consulting the commissioner of the navy was required, since otherwise he [the captain] would be responsible for any effects turned over without permission. ${ }^{67}$

At the same time the Spanish military governor informed Grimaldi at length, explaining that he had allowed to English to come with their machines and equipment for salvaging the frigate. Since he did not have the proper tools himself, he wanted to avoid having "the Emperor allege at any time that we had presented obstacles to recovering the ship." He added that if the captain was not given the provisions and assistance required by the Peace Treaty of 1767 it

65 Julián de Arriaga to Marquis of Grimaldi, Aranjuez, 16 May 1774, AHN, Estado, leg. 5802.

66 “...hallándose la embarcación mucho mas inmediata a Gibraltar y teniendo allí los aparejos y útiles a propósito, de que se carecia por nuestra parte, creyó el Arraez seria mejor valerse de los Yngleses, no ha querido admitir ningun socorro de los nuestros: bien que el Governador Yngles se puso de acuerdo con el Comandante del Campo de San Roque antes de ofrecerse a hacer las faenas": draft letter to T. Bremond, dated in Aranjuez 20 May 1774, AHN, Estado, leg. 5802 .

67 “...que se hicieron las ofertas correspondientes por nuestra parte, que en efecto no había allí los aparejos y útiles necesarios, ademas de ser mayor la distancia, y que la formalidad de exigir el Comisario de Marina era precisa, pues de otra suerte se hacia el mismo responsable de los efectos que entregase sin ella": Aranjuez to Tomás Bremond, 2o May 1774, AHN, Estado, leg. 5802. 
was because of his refusal to accept them, since he preferred to obtain them from Moroccan merchants established in Gibraltar:

After the shipwreck the captain of the frigate had asked for some foodstuffs, basing himself on Article 4 of the Peace Treaty negotiated with that prince, that in cases of shipwreck any help should be given without payment or for no more than the fair price.

The difficulty arose when the local Minister of the Navy agreed to give the captain what he wanted, but asked for payment. The city magistrate ordered that

for greater speed he provide immediately everything that the captain was requesting, with a notice of its fair price. But when [the captain] heard that he would have to pay for what was being sent he refused to accept it, claiming that it was easier for him to be supplied from Gibraltar, where some Moors were established and victuals could come from his own country. In view of this I gave permission for five of them to go every day to fetch them, as the captain had asked me to, and I hear that the English gave them some through their consul; although afterward a boat came from Tetouan with some food, which they received through that port. ${ }^{68}$

The supply chain from Morocco was interrupted, however, forcing the Spanish authorities to advance funds to the captain ("since he had not brought any") to buy provisions. Vice consul Pacheco reported that

the captain needed victuals because he had consumed all those that came from Tetouan; as a result he has been offered and has been receiving daily all that he asks for, for which we have advanced him money, since he had not brought any. But on the 21st the captain declared that the English had complained about his receiving food from us and offered to give it to him, as they had done at the beginning; and if he did not accept they would

68 “...para mayor prontitud, embiase en el momento quanto el Arraez pedia, con noticia de su justo valor, pero al oir este, que lo que se le embiava era con responsabilidad al pago, no lo admitió, diciendo tenia mas facilidad para proveerse por Gibraltar, donde hay algunos Moros establecidos, y podrían venirle los Viveres de su Pais, en vista de lo qual les di un permiso para que diariamente fuesen cinco de ellos a traérselos, segun el Arraez me pidió, y tengo entendido que los Yngleses les subministraron algunos, por medio de su Consul, aunque después vino un Barco que les trajo de Tetuan una porción de comestibles, que recibieron por la dicha Plaza": Agustín de Mendoza Pacheco to Marquis of Grimaldi, Campo de Gibraltar, 23 May 1774, AHN, Estado, leg. 5802. 
cease their efforts to salvage his frigate. To this he replied that since our consul had come by order of his sovereign to help them, [the English] should settle things with him, since nothing could be resolved until they dealt with him. ${ }^{69}$

In Mendoza's opinion the English, by intervening, meant to show themselves to the sultan as the saviors of the frigate and its crew, so as

to flatter the emperor of Morocco and persuade him that even though his frigate is on our territory, they are the ones who have made great efforts to salvage it and attend to the needs of its people. ${ }^{70}$

Spain decided to agree to the demands of the English so that, in case the salvage operations failed, England could not accuse Spain of having placed obstacles in their way:

It may not be a false pretext for desisting from this enterprise; for if we continued to provide supplies, thinking them unobtainable otherwise, [the English] could then claim that a failure to salvage the ship arose from this cause. It seems to me wiser to give them no occasion for this excuse by ceasing to give victuals to the Moors and letting them get them from the English. I proceed in agreement with the captain, whom the consul has informed of the reasons for my decision; and [the consul] is of the same mind, since he understands my thinking. ${ }^{71}$

69 " [E]l Arraez, necesitava de viveres, por haverse consumido los venidos de Tetuan, y en su consequencia, con mi acuerdo le ofrezió, y ha estado subministrándole diariamente todos los que ha pedido, para lo qual le he facilitado Dinero, pues el no trajo alguno; pero el dia 21 expresó el Arraez, que los Yngleses se le havian quejado, por que recivia los viveres de nuestra parte, ofreziendole que ellos se los darían, como hizieron al principio, y que si no los admitia cesarian en las diligencias de salvarle la Fragata, a lo que el havia respondido, que como nuestro Consul havia venido, embiado por su Soberano, para asistirles, se entendían con el, y que hasta tratar con el mismo, no podía resolver": Agustín de Mendoza Pacheco to Marquis of Grimaldi, Campo de Gibraltar, 23 May 1774, AHN, Estado, leg. 5802. “...obsequiar al emperador de Marruecos, con la máxima de hacerle ver, que aun estando su Fragata en nuestro territorio, han sido ellos los que se han esmerado, en los esfuerzos para salvarla, y en cuidar de la subsistencia de su Gente": Agustín de Mendoza Pacheco to Marquis of Grimaldi, Campo de Gibraltar, 23 May 1774, AHN, Estado, leg. 5802.

71 "T T]al vez no puede ser un artificioso pretexto, para desistir de la empresa, si por nuestra parte se continuase subministrando los viveres, por contemplarla inascesible, y que después podrían decir, que el no haver sacado la embarcación, dimano de esta causa, me ha parecido lo mas acertado, quitarles la ocasión de este efugio, cesando aca en dar á los Moros los viveres, y dejando que los recivan de los Yngleses, procediendo de acuerdo 
In the meantime the English were proceeding with the salvage operation:

They have caulked it to stop the large amounts of water it was taking in, and have dispatched one of their frigates to Barbary with letters for the sovereign. They request, among other things, more wood for the ribbing (since they do not have those pieces) to patch the hole in the frigate's hull, which is now closed superficially. They offer to provide gratis from their own warehouses the other timbers that are needed. ${ }^{72}$

The English in Gibraltar asked the captain to bring them the rigging and any other salvaged parts so that they could determine what was usable and what needed to be replaced. Unwilling to give an inch, the captain replied "that since those effects were in Spanish territory he could not comply." Commander Mendoza, after consulting the captain, "two other Moorish officers," and Vice Consul Francisco Pacheco, agreed to await the decisions of the Moroccan and Spanish monarchs, "particularly since the frigate cannot be left for long in need of the equipment mentioned."

The captain moved to Gibraltar at the request of that city's governor. There he was reprimanded for having left the frigate where it was stranded and not having brought the crew, the rigging, and the other equipment; this complaint was relayed to the sultan. The captain argued that the commander of the Gibraltar region had not let him do so, "but the governor will not believe me." The Spanish official in charge cared more for what the captain had written to his sovereign, declaring

how satisfied he is with the assistance and attentions he has received from us, and it is true he has no reason to feel otherwise, for he and all his crew have been attended to with special care in everything: their sick are taken to be cured in the hospital at Algeciras, where they are singled

con el Arraez, á quien el Consul le ha hecho conocer las razones en que se funda mi determinación, siendo él del mismo parecer, por compreender la propia Ydea": Agustín de Mendoza Pacheco to Marquis of Grimaldi, Campo de Gibraltar, 23 May 1774, AHN, Estado, leg. 5802 .

72 "[L]a han galafateado, para quitarle la entrada de la mucha Agua que hazia, y han despachado una Fragata suya á Berberia, con cartas para el dicho Soberano, asegurándose, que entre lo demas de que tratan piden alguna Madera de Costillaje, cuyas piezas no tienen ellos, para ponerla en la rotura del Plan de la Fragata, que superficialmente le han tapado, ofreciéndose á franquear de sus Almazenes, las demas Maderas que se necesitan": Agustín de Mendoza Pacheco to Marquis of Grimaldi, Campo de Gibraltar, 9 June 1774, AHN, Estado, leg. 5802. 
out, and the officers and all the frigate's people are supplied daily with what the captain requests for their sustenance, though no more than the bare necessities. And I continue to advance to Vice Consul Don Francisco Pacheco the funds that he needs for this. ${ }^{73}$

Mendoza also told Grimaldi that while the governor of Gibraltar was prepared to accept the nautical supplies, he was reluctant to receive the crew. Therefore, after consulting Captain Asseri, the alcaide Abdelmagid who accompanied him, Tomás Bremond, and Francisco Pacheco, he decided to

charter a Spanish ship in Algeciras to convey the supplies and crewmen to Gibraltar, with Pacheco attending them as far as that port if its governor would accept them; and if he does not allow them entry, to continue their passage to Tangier.

After a long delay that Mendoza claimed not to understand, the transfer was finally made in July. ${ }^{74}$ Gibraltar's English governor, Robert Boyd, told Mendoza that he had not sent for the supplies, the captain having informed him that "he and his crew, with the nautical equipment that had remained on land, had all been embarked by order of Your Excellency"; he therefore awaited the Spanish commander's final decision as well as the sultan's. ${ }^{75}$ Mendoza soon replied that, following the sultan's orders, the equipment had been sent to Gibraltar in a Spanish ship, with a second ship carrying the crewmen and their baggage. ${ }^{76}$ The crew was finally sent on to Tangier:

73 “...lo mui satisfecho que está de los auxilios, y atenciones que ha encontrado en nosotros, y en realidad no tiene razón para otra cosa, pues se le atiende, y juntamente á toda su Tripulacion con especial cuidado, en quanto les ocurre: sus enfermos se llevan á curar al Hospital de Algeciras, donde se les distingue, y á los oficiales, y toda la Gente de la Fragata se les subministra diariamente quanto el Arraez pide, para su subsistencia, aunque este se ciñe solo a lo preciso, y yo continuo franqueándole al Vice-Consul Don Francisco Pacheco el dinero que para ello necesita": Agustín de Mendoza Pacheco to Marquis of Grimaldi, Campo de Gibraltar, 9 June 1774, AHN, Estado, leg. 5802.

74 “...fletar un Barco Español en Algeciras, en que se llevasen los dichos Pertrechos y moros á Gibraltar, yendo con ellos el citado Pacheco, para dejarlos en aquella Plaza, si el Governador se conformava, y de no admitirlos, seguir su viaje a Tanger": Agustín de Mendoza Pacheco to Robert Boyd, governor of Gibraltar, Campo de San Roque, 8 July 1774, AHN, Estado, leg. 5802 .

75 Robert Boyd to Agustín de Mendoza Pacheco, Gibraltar, 9 July 1774, AHN, Estado, leg. 5802.

76 Agustín de Mendoza Pacheco to Robert Boyd, Campo de Gibraltar, 27 July 1774, AHN, Estado, leg. 5802. 
Yesterday Captain Abdalá el Lasseri arrived in this [port] from that of Gibraltar together with the crew of this sovereign's frigate that was wrecked on our coast. They were escorted by Hach Belabes Moreno, who went by order of the emperor to fetch them from that port; His Majesty having received a letter from its governor stating that he could not receive them, in spite of his having instructed me to hand them over there, along with the supplies. After receiving this news he decided to send for them, and because of what the governor of Gibraltar writes to him he has decided to suspend work on the house being built in Río Martil for the British consul. ${ }^{77}$

Francisco Pacheco, Spain's vice consul in Tangier, informed the sultan of Morocco that "your servant Abdala El Asseri" had been given "the Moors, clothing, and equipment of your royal frigate that ran aground in Spain," and added that "not the slightest thing of all that was salvaged remains in Spain."78 The captain provided Pacheco with a receipt stating that he "was satisfied" with the handover, which had taken place in Gibraltar. ${ }^{79}$

The operation with the frigate had led to considerable costs, although "strict economy" had been attempted:

We have spent 11,171 reales and 16 maravedís de vellón on the victuals supplied, the charter of a ship, and other items, in their long residence here; this includes food for the captain, the officers, and all the crew, who numbered seventy men. For a time fourteen of them were in Gibraltar at the request of the English to work on the frigate, before all the people [arrived there]; and we took them food from here every day, because it was not provided to them in that port. ${ }^{80}$

77 "Ayer llegaron a esta de la de Gibraltar el Harraez Abdalá el Laseri, y Tripulacion de la fragata de este soberano naufragada en nuestra costa, conducidos por el Jach Belabes Moreno, quien pasó de orden del Emperador a buscarlos a aquella Plaza, por haver recivido S.M. carta del Governador, en que le dezia no podía admitirlos, no obstante haberme dado a mi la orden para que los entregara allí con los Pertrechos; luego que tubo esta noticia dispuso mandar por ellos, y de resultas de lo que le escribe el Governador de Gibraltar, ha mandado suspender la obra de la Casa que se fabricaba en Martil para el Consul Britanico": F. Pacheco to T. Bremond, Tangier, 12 August 1774, AHN, Estado, leg. 5802.

78 F. Pacheco to the sultan of Morocco, Tangier, 6 August 1774, AHN, Estado, leg. 4312.

79 F. Pacheco to the sultan of Morocco, Tangier, 6 August 1774, AHN, Estado, leg. 4312.

80 " [S] han gastado onze mil ciento setenta y un reales y diez y seis maravedís de vellón en los viveres que se les han dado, flete del Barco y otras ocurrencias, en la larga mansion que han tenido aquí, comprendida en esto la comida para el Arraez, y demas oficiales, y de toda la Tripulacion, cuyo numero era de setenta Hombres, pues hasta en algun tiempo que catorze de ellos estubieron en Gibraltar, á solicitud de los Yngleses, para trabajar en 
The captain and crew gave a very good account of their treatment at the hands of the Spanish:

As soon as they landed they proclaimed how well they were dealt with in Spain all the time they were there, and the captain informed the Pasha of everything in detail, in my presence, [saying] that he will tell his master the same, since he is so grateful. They say that after leaving Spain they were not satisfied with their provisions, and [they say] many other things of this kind that speak in our favor. ${ }^{81}$

Consul Tomás Bremond, who was in Fedala at the time, had followed the matter closely and "could support these accurate explanations, in case there should arise any complaint that the captain of the frigate of His Moroccan Majesty might bring." 82

It is clear that the salvaging of the frigate and the aid given to its crew gave rise to a significant dispute between the Spanish and the English, both of whom were contending for the favors of the Moroccan sultan. The Spanish considered the affair a victory that allowed them to continue in his good graces; but only a few months later war broke out between Spain and Morocco after the latter country attacked the Spanish enclave of Melilla.

\subsubsection{Qaddur Saibanu and Hoda (1777)}

In 1777 two corsair galliots under Captains Qaddur Saibanu and Hoda ${ }^{83}$ passed near Ceuta, whose fortress fired on them with

la Fragata, antes que fuese toda la Gente, se les llevava de aquí la comida todos los días, por no havérsela facilitado en aquella Plaza": Notebook signed by F. Pacheco with the amounts spent on the frigate's crew and other items, every day from 17 May to 27 July 1774. Transport was paid for at least four crewmen to the hospital in Algeciras. Agustín de Mendoza Pacheco to Marquis of Grimaldi, Campo de Gibraltar, 5 August 1774, AHN, Estado, leg. 5802.

81 "[L]uego que llegaron a tierra publicaron el bien que en España se les hizo todo el tiempo, que allí estubieron, contando dho Harrez al Baxá en mi presencia todo por estenso, y que asi lo informará a su Amo, por lo mui agradezido, que biene, pues dizen, que desde que salieron de España no se han visto satisfechos de sustento, y á este tenor otras muchas cosas que hablan á nuestro favor": Tomás Bremond to Marquis of Grimaldi, Madrid, 23 August 1774. Francisco Pacheco to Tomás Bremond, Tangier, 12 August 1774, AHN, Estado, leg. 5802 .

82 Tomás Bremond to Marquis of Grimaldi, Salé, 9 June 1774, AHN, Estado, leg. 5802.

83 The former may be the Shaybanyni and/or Saybano who figures in J.L. Miège's list of captains: "Course et marine," 216-17. There is no other documentation of Hoda. 
twelve cannon shots and some rifle fire. Surprised by this, the Moors raised their accustomed signal to be recognized as Moroccans, and shouted through megaphones that they came in peace. To this those on shore replied that they did not have it [sic], and four xebecs of our Lord King pursued them to the river's mouth, which they entered with all their sails in tatters from the shots they had received from the port, though no man was wounded.

Captain Ahmad Mostaganim, who was in Tetouan at the time, convinced Saibanu and Hoda not to complain to the sultan, arguing that "the Spaniards would not have done such a thing if they had known for sure that the ships belonged to the [Moroccan] king their master; but since the hour was late, they must have suspected they were Algerian." ${ }^{84}$

\subsubsection{Al-Arbi al-Mistiri (1772-1780)}

In $177^{2}$ Captain al-Arbi al-Mistiri, finding his ship in difficulties, headed to Algiers where he hoped it could be repaired. As there was no help there he went on to Cartagena, presumably with the same intent. ${ }^{85}$ There he had a confrontation with the military governor when he demanded, somewhat rudely, that some Moroccans seized out of an Algerian corsair ship be turned over to him. ${ }^{86}$ In October 178 o the Moroccan sultan wrote to Antonio de Gálvez, chief treasurer of Cádiz, announcing that Captain al-Mistiri would give him 200,000 pesos fuertes as a deposit. ${ }^{87}$ On 9 October the captain arrived in Cádiz in command of the twenty-four-gun Moroccan frigate El Tigre with a crew of one hundred men. He brought the stipulated sum with orders to acquire schooners and nautical equipment: "we order you that the note that Captain al-Mistiri will give you for the necessary cordage be honored with the consent of the commander and the governor." 88

84 “...doce cañonazos, y porción de tiros de Fusiles, a esta novedad, dizen pusieron los Moros la señal que suelen usar para que los reconocieran por Marroquíes, y con las vocinas les decían eran de Paz, a que respondieron los de tierra que ellos no la tenían; luego las siguieron quatro Javeques del Rey N.S. hasta la Boca del rio donde entraron con todas las velas hechas pedazos del fuego que recibieron de la Plaza, sin haver herido hombre alguno. ... [L]os Españoles no hubieran hecho tal cosa, si supieran de fixo, que las Embarcaciones pertenecían al Rey su Amo; pero que como era tarde, sospecharían ser Argelinos": J. Patissiati to Count Floridablanca, Cádiz, 6 May 1777, AHN, Estado, leg. 3412.

85 T. Bremond to Marquis of Grimaldi, 5 December 1772, AHN, Estado, leg. 4312.

86 See section 7.1. Also T. Bremond to Marquis of Grimaldi, 15 November 1772, AHN, Estado, leg. 4312 .

87 Letter from the sultan to Gálvez dated 1 October 1780, AHN, Estado, leg. 4315.

88 Dated 3 September 1780, AHN, Estado, leg. 4315. 


\subsubsection{Aly al-Hamsaly (1781-1795)}

This captain was involved in several incidents in Spanish ports. ${ }^{89}$ In 1781 the Moroccan sultan sent him to Cádiz with two thousand pesos fuertes to be spent on various commissions, but what he bought cost almost forty thousand. The Spanish authorities were disturbed because the monarch had not made clear who would pay those costs. Further, on the captain's return to Tangier he demanded the return of the original two thousand pesos entrusted to him. ${ }^{90}$ The Spanish consul general in Tangier informed Ibn Utman in person and in writing of al-Hamsaly's conduct in Cádiz - marked by "threats, disorder, and arrogance" - in hopes that the sultan would learn the facts and punish him "as an example to others." 91

In 1782 al-Hamsaly was back in Cádiz where he was issued equipment, tools, and victuals to a total value of 229,345 reales de vellón. He received timbers, pulleys, rigging (tarred, English white, and northern), fabrics, bitumen, thick and thin nails, metals, lanterns, hardware, locks and keys, paint, oars, sails, almost two thousand bullets and cannon balls, ten sacks of shrapnel, anchors, and food, especially for daily rations for ten officers of the frigate. ${ }^{92}$

89 He also appears as Mahamet Alejansali and Mahamet Janseli.

9o Count Floridablanca to José Boltas, head of the Franciscan mission in Morocco, San Lorenzo de El Escorial, 19 October 1781; another letter of 5 November 1781, AHN, Estado, leg. 4317. Also Count Floridablanca to J.M. González Salmón, 19 October 1781, A HN, Estado, leg. 4316.

91 J. M. González Salmón to Count Floridablanca, Tangier, 21 August 1781, AHN, Estado, leg. 4314.

92 "Account of the items supplied to His Moroccan Majesty's war frigate named El Tigre, which entered the Bay of Cádiz on 11 December 1781. They have been issued from 5 January of this year to 3 May of the same for repairing and restoring its hull, according to the reports, extracts, and certificates sent by the shipyard of La Carraca; these come to this Chief Accounting Office with the sum of their value, which has been assessed by the Acting Chief Engineer Don Joaquín Ibarguen, together with an accounting of the victuals and other expenses that are described in the following reports" ("Relacion de los géneros subministrados a la Fragata de Guerra de S.M. Marroqui nombrada El Tigre, que entró en la Bahia de Cadiz en once de Diciembre de mil setecientos ochenta y uno y se le han facilitado desde cinco de Enero de este año hasta tres de Mayo del mismo para su Carena y habilitación según consta de las relaciones, extractos y certificaciones remitidas del Arsenal de la Carraca, que paran en esta Contaduría Principal con el importe de sus valores que han sido valuados por el Yngeniero Comandante interino Dn. Joaquin Ibarguen; como asi mismo de los viveres y demás gastos que se manifiestan en las partidas siguientes"). The total included salaries for the engineers, carpenters, turners, and blacksmiths. Signed by Juan de Ulloa, Isla de León, 3 June 1782. Also Marquis of González Castejón of the Secretariat of State to Count Floridablanca, San Ildefonso [El Escorial], 29 July 1782, AHN, Estado, leg. 5820 . 
In 179o the frigate El Tigre was rebuilt "to the satisfaction of its Moroccan captain, Mahamet Alejansali," who also asked for eighteen 8-inch guns and six 4-inch ones. ${ }^{93}$ The consul general in Morocco suggested that when the captain departed he be offered special treatment, "since he seems to be favored by the new king [al-Yazid]":

This captain has expressed great satisfaction with his good reception in Cádiz, and gave very good reports to the late king of Morocco of how well the frigate had been repaired. A little before that prince's death the captain had asked to be given a set of cannon for the vessel, and it was suggested to him that it could not be done because His Moroccan Majesty had not requested it.

\section{Al-Hamsaly had spoken to the Admiral of the Fleet}

about having informed his new sovereign of the state of the frigate, praising highly the care that had been taken with it. As a result the Governor of Tangier has told him that by orders of His Moroccan Majesty forty men will be sent to Cádiz to sail the ship to Larache, where a royal salute has been prepared, and likewise in the other ports that His Moroccan Majesty shall decide.

The Admiral presumed "that this is a new hint that we should give him artillery." The Minister of the Navy agreed and informed the Secretary of State that the captain's "hint" should be taken up. ${ }^{94}$ In any event a decision was requested from the Secretariat of State in case there should be "some inconvenience arising from this new solicitation," but the answer came that "the king of Morocco

93 The number of cannon comes in an unsigned, undated note: Antonio Valdás to Count Floridablanca, Aranjuez, 6 April 179o, AHN, Estado, leg. 5820.

94 "Este arráez se ha mostrado muy contento de lo bien que se le ha tratado en Cádiz; y dio muy buenos informes al difunto Rey de Marruecos de lo bien que se componía la fragata. Poco antes de morir aquel Príncipe pidió el mismo Arraez se le diese una porción de cañones para aquel buque; y se le insinuó no haberlo pedido S.M. Marroqui y por eso no se le podía dar. ... de haber dado cuenta a su nuevo Soberano del estado de la fragata alabando mucho el esmero que se ha puesto en ella, de que ha resultado avisársele por el Gobernador de Tanger, que S.M.M. ha mandado pasen a Cadiz 40 hombres para conducirla a Larache donde está dispuesto haya salva real y sucesivamente en los demás puertos donde concurra S.M.M.": Antonio Valdés, Minister of the Navy, to Count Floridablanca, Aranjuez, 20 April 179o; and another document dated in Cádiz, 1 June 179o, AHN, Estado, leg. 5820 . 
has made no such request and therefore it cannot be granted"; the vice consul in Tangier would inform the sultan that "our laws forbid it." If it became necessary the required sum would be paid, but it was recalled that once before the sultan had asked for guns and gun carriages from the factory in Seville, offering to pay for them, but had been denied. He should not believe that on the pretext of purchasing "he will be given weapons and munitions gratis," and "we should avoid [such situations] whenever we can because of the ill effects they can have with respect to other nations." ${ }^{95}$ While the Secretariat of State was gratified by the captain's speaking "to his new sovereign about his good treatment in Cádiz and the care with which the frigate was repaired," providing artillery was out of the question. ${ }^{96}$

Finally Luis de Córdoba, Admiral of the Fleet, could report that El Tigre was ready to sail for Larache and Mogador, where the sultan awaited her

to witness the salute that will be celebrated in praise of Spain. [But] for the desired effect [al-Hamsaly] repeats that he should be allowed the artillery that he requested earlier, for without it he cannot obey his sovereign's order; as a result he will risk his person, because he assured [the sultan] that he would also be given artillery, assuming this because cannon had been supplied to other frigates of this prince. ${ }^{97}$

Matters had reached this stage when authorities in Cádiz confiscated some valuables from one of the ship's officers, as Consul Juan Manuel González Salmón reported:

... a seizure from an officer of his warship in this seaport of four dozen Barcelona kerchiefs and six ounces of gold, [with a complaint] of the poor treatment he received. [I enclose] a copy of the reply I gave him, and another of what I wrote to the governor about the matter; and he has answered by word of mouth that they will try to assist the captain as best they can, but that it is essential to follow regulations.

95 Aranjuez to Antonio Valdés, 14 June 179o, AHN, Estado, leg. 5820.

96 There is a crossed-out passage in the draft: Aranjuez to Antonio Valdés, 10 June 179o, AHN, Estado, leg. 5820.

97 “...para asistir al saludo, que ha de celebrar en aplauso de España: para el mencionado efecto repite se le franquee la artillería que pidió en fecha anterior por no poder sin ella cumplir la orden de su Soberano, con quien incurrirá en inconsecuencia, exponiéndose su Persona, por haverle asegurado, que se le facilitaba también artillería: bajo este supuesto, y el de haberse franqueado cañones a otras fragatas de este Príncipe": Antonio Valdés to Count Floridablanca, Palacio, 27 July 1790. 
Hamsaly reported in writing to the governor of Cádiz stating that he had sent one of his officers to collect some silk kerchiefs and a watch, for which he had already arranged. As the man was returning to the ship (with the kerchiefs but without the watch - he had been unable to find the watchmaker), guards of the port had confiscated the kerchiefs and some coins. Hamsaly complained that the official had been "pushed and shoved" and mocked for his religion - on that point, the guards had "displayed their private parts." He asked the governor for written instructions on how to act in the future, "for you know how little knowledge we have of Spanish customs." Were it not for "the great love and trust I have for you," the Moroccan captain would have addressed his complaint to the Court; in a curious note of flattery he claims that "I therefore make you my Court."

González Salmón did not wish to offend the captain, to ensure that he would give a good report to the sultan on his reception in Cádiz:

If the matter is not settled in the Moor's favor it will come to the attention of the Moroccan sovereign, and it is not worth raising it to that level or displeasing the captain when on some [other] occasion he could be of use and be inclined toward us. When I welcomed him he told me that I would hear of the report he would give the king his master about us and the repair of the frigate. I think that the frigate will not sail when I do, because the captain himself says that it is not wholly repaired. But for my report to the sultan, without letting him suspect that it is to remind him of our service, I have ordered a drawing made of it under full sail, in a fine frame, to present to him or his ministers during one of his audiences at court. 99

98 The report is dated 7 July 179o, presented at the Isla de León and signed in Arabic: AHN, Estado, leg. 4322.

99 “...apreension que se ha hecho a un oficial de su Buque en esta Puerta de la Mar de 4 dozenas de Pañuelos de Barcelona y 6 onzas de oro y el mal trato que se le dio; copia de la respuesta que le puse, y otra de lo que con dicho motivo he escrito a este Cavallero Governador, quien me ha respondido a boca se procurará atender al Harraez lo mejor que se pueda pero era indispensable seguir los Autos.... [S]i no se resuelve afavor del Moro ha de llegar el asunto a noticia del Soberano Marroqui, y no merece la pena de que trascienda a tanto, ni que el Harraez salga disgustdo en ocasión qe nos puede valer, y que se nos manifiesta inclinado pues quando le hize el agasajo me ofrecio que ya oiría yo el informe que daba de nosotros y de la composición de la Fragata al Rey su Amo. Dicha Fragata no creo salga conmigo porque he sabido por el mismo Harraez no se halla aun del todo avilitada, pero para hazer memoria de ella al Soberano, sin que sospeche es con la idea de recordarle este servicio, he mandado sacar un diseño de ella puesta a la Bela colocada en un marco primoroso para presentárselo, ó a sus Ministros en una de las Audiencias que tenga en aquella corte": J. M. González Salmón to Count Floridablanca, Cádiz, 13 July 179o; 
Not only were the confiscated kerchiefs and gold returned, but the captain was given one hundred pesos fuertes "in cash as a way of satisfying him, explaining that it was done so that he could buy whatever items he most desired." His first mate and his interpreter received twenty-five pesos fuertes apiece. 100

Al-Hamsaly still caused one more problem, whether by omission or commission. The frigate finally sailed (without the desired guns or gun carriages) on 24 July, ${ }^{101}$ while at the same time a barge was being loaded with equipment for the frigate to be taken to Larache. ${ }^{102}$ Captain al-Hamsaly anchored in Larache on 27 August, and it was then discovered that he had stowaways on board:

His Moorish crewmen have brought two Christian lads, thirteen and eighteen years old, one from Havana and the other from La Isla de León; and when our trusted man in that port tried to have them turned over to him, he was told that they already professed the Mohammedan religion. ${ }^{103}$

The barge was forbidden to sail, but by the time the order reached Cádiz it had already left in convoy with the ship Gallardo. ${ }^{104}$

Al-Hamsaly reappeared the following year: in May 1791 he was in Ceuta bearing letters from Sultan Muley al-Yazid to Charles Iv. He claimed to have orders to meet Captain Ibrahim Lubaris, who was in Cádiz at the time, before going

draft, AHN, Estado, leg. 4316. According to the consul, the captain had argued that the officer in question "had gone in good faith, under his instructions, to buy those kerchiefs and a watch that he himself had ordered, but not finding the watchmaker he had returned with the money." The Moroccan's person had been searched "violently and indecently; and he asked [his captain] if, making little of his ignorance of our rules, he might find a way to have his kerchiefs and his money returned." The consul approached the governor of Cádiz explaining that the captain, "irrespective of the right or wrong of this case, is now in a position to assist us at the Court of Morocco, since he already has the new king well informed of the repair of the ship and the good treatment he has received," adding that he would be pleased if the goods should not be confiscated: Palacio to Pedro de Lerena, 24 July 179o; Pedro de Lerena to Count Floridablanca, 29 July 179o, AHN, Estado, leg. 5820. González Salmón's accounting of the expenses incurred for Mahamet Essuin from the day of his disembarkation, 5 June, to 9 July; also of the gift offered to Captain Mahamet Hansaly of the Moroccan frigate, Cádiz, 13 July 179o, AHN, Estado, leg. 4316.

101 The consul sent the sultan an "Illustration of the frigate beautifully painted," which he placed in "a fine frame": J.M. González Salmón to Count Floridablanca, 2 and 13 September 1790, AHN, Estado, leg. 4322.

102 The barge would carry its usual complement as well as a second pilot experienced in navigating those coasts; it was awaiting its sailing orders. Antonio Valdés to Count Floridablanca, 29 August 1790, AHN, Estado, leg. 5820.

103 San Ildefonso to Antonio Valdés, 9 September 179o, A HN, Estado, leg. 5820.

104 Antonio Valdés to Count Floridablanca, 31 August 1790, AHN, Estado, leg. 5820. 
on to Madrid, so Ceuta's governor chartered a ship for him and his eight companions; reaching Cádiz on 13 May, they then traveled to the Spanish court. Al-Hamsaly told González Salmón that he was conveying the ratification of the Treaty of Peace, and that any disagreements between Spain and Morocco had already been settled to Spain's satisfaction; but in fact the treaty was not signed, and war broke out between Spain and the portion of Morocco ruled by Muley al-Yazid. Al-Hamsaly reached Aranjuez on 31 May but by 9 July he was back in Ceuta, having sailed from Gibraltar. ${ }^{105}$

In 1795 al-Hamsaly was the protagonist of yet another incident, this time on the high seas: he made an illegal capture of the Spanish frigate Sacra Familia, homebound from Buenos Aires. This time Spain did not hesitate to ask Muley Sliman to punish him, and he was imprisoned - a step especially appreciated because it was taken even before the complaint from the Spanish vice consul in Tangier had reached the Moroccan court. Still, Prince Muley Taib's interest in the captain was considered an advantage: had the prince not mediated in the affair it might be thought that Spain had acted out of vengeance, endangering the countries' mutual relations. "Thanks to his generous action of pleading for him, we have let them see that we have no other thought than to preserve good order and friendly intelligence between the two nations."106

\subsubsection{Aly Sabuni (1785)}

In 1785 Captain Aly Sabuni ${ }^{107}$ arrived in Cartagena in command of the Moroccan war frigate La Manzora, with sixteen guns and a crew of fifty-four, in search of provisions. He claimed to have orders from the sultan "to obtain the replacements he needed to continue his corsair expedition, and also for a supply of victuals for only three days, asking that all of it be given him free of charge." The admiral of the Cartagena region informed Sabuni that he was not allowed to provide military equipment to North African countries, and that furthermore, since July 1783 he could supply food only if it was paid for or he was given a receipt:

He is under orders to not supply food to the warships of any nation, with no exception made for African ones, unless their fair price was paid. And as for naval equipment, since His Majesty had forbidden it for all the African Regencies it would be very wrong to supply it to Moroccan ships. However, as a particular favor to that sovereign, if the captain had no

\footnotetext{
105 Arribas Palau, "Nuevos datos sobre moros en la Alhambra."

106 J.M. González Salmón to Duke of La Alcudia, Cádiz, 23 June 1795, AHN, Estado, leg. 5818.

107 Also called Alí Sabury, Ali Sabusi, Alí Sabony and Alí Sabungi.
} 
ready money to pay for the victuals he needed he could offer a receipt that specified what he received and its value, so that it could be sent to His Moroccan Majesty. As a single favor free refreshments would be offered him, as it appears has already been done. Likewise, if some item should be required for a temporary repair of the ship, it should also be done properly with a receipt and in form, telling him that it will be sent to His Moroccan Majesty; for with any concession of this sort it is natural to inform the king either directly or through you. And even then, no difference should be made among Mediterranean ports for the reasons already indicated with respect to the Regencies. ${ }^{108}$

The captain was notified that everything he had asked for would be recorded in a message to the sultan. ${ }^{109}$ In spite of the prohibition, however, he received the following items: two anchors measuring respectively ten and eleven inches, four cables of fourteen, twelve, seven, and six inches respectively, a full set of sails, a few pieces of rigging of different lengths, a skiff, a stern lantern, and a spar for the mizzenmast. There were also foodstuffs "for two months at sea, as well as fresh supplies of meat, ship's biscuit, flour, rice, and lard," together with two quintales of firewood and four large baskets of charcoal. ${ }^{110}$

The Spaniards were displeased with the captain's attitude, and the Spanish consul general was ordered to "make the incident known to the [Moroccan]

108 "[S]e halla con ordenes para no subministrar viveres á los buques de nación alguna sin exceptuar los Africanos sino pagando su justo valor, y que en quanto a los pertrechos navales habiéndolos negado S.M. á todas la Regencias de Africa seria muy reparable suministarlos á las embarcaciones Marroquies; pero que sin embargo por consideración particular a ese Soberano, si el Arraez no tuviese dinero para pagar los viveres que necesite de pronto, deberá dar un recibo especificando lo que le entreguen y sus valores para qe pueda enviarse a S.M.M. haciéndole únicamente alguna demostración gratuita de refrescos como parece que lo ha executado ya: y que igualmente si para habilitar provisionalmente la embarcación fuere preciso dar al arraez algun pertrecho sea también baxo igual recibo, y regulación diciéndole que se remitirá a S.M.M. quien quando quiera alguna condescendencia de estas es natural la avise al Rey directamente o por medio de Vm. y aun entonces no se podrá diferir en los puertos del Mediterraneo por los motivos ya indicados respectivos a las Regencias": Count Floridablanca to J. M. González Salmón, Madrid, 6 December 1785, AHN, Estado, leg. 4316.

109 He was later accused of having entered the port for no reason, and of having requested "a multitude of things more on a whim and frivolously than by necessity": J.M. González Salmón to Count Floridablanca, Darbeyda, 14 October 1786 and 12 March 1787, AHN, Estado, leg. 4319 .

110 "Nota de los efectos que ha pedido del arsenal de Cartagena el arráez Ali Sabusi de la fragata Marroqui de guerra la Manzora," 6 December 1785, AHN, Estado, leg. 4316. 
sovereign without delay"111 Having done so, he reported that the sultan was grateful for Spanish assistance and that such behavior would cease, because captains would bear "letters when they need to request anything."112

\subsubsection{Ibrahim Lubaris (1786-1791)}

An illuminating case is the conduct of Captain Ibrahim Lubaris after his frigate was wrecked off the Spanish fortress of San Felipe, between La Línea and Gibraltar, in late 1785 . He requested and was granted assistance:

[Since it] needs all kinds of help to fund and repair it, orders have been issued to supply it with everything including necessary victuals so that the sovereign may be completely satisfied in this regard. ${ }^{113}$

Lubaris asked for a full new set of sails for his frigate, "claiming that he will lose his head if he returns home with the old one, which is in a poor state." The Secretary of State ordered the military governor of the Gibraltar region, the Marquis of Zayas, to comply with this request

to replace the old sails. It will be arranged for the new set to be sent from Cádiz, but it should not be delivered until you hear from Morocco about these individual petitions from that prince's captains. ... The king wishes to satisfy him, but first he wants to know if it is his pleasure, to avoid any misunderstandings on the part of the captains. ${ }^{114}$

In fact it was necessary to go to Cádiz for new sails, because

111 J.M. González acknowledged these instructions in a letter to Count Floridablanca, Darbeyda, 27 January 1786, AHN, Estado, 4316.

112 J.M. González Salmón to Count Floridablanca, Darbeyda, 31 January 1786. The sultan knew that the captain himself had appreciated his reception: "he has informed us of how warmly the Spaniards treated him": translated letter from His Moroccan Majesty to J.M. González Salmón, 13 March 1786, AHN, Estado, leg. 4319.

113 "[N]ecesitando todo genero de auxilios para ponerla en franquicia y repararla, se han dado ordenes para que todo se subministre como también los viveres necesarios, de manera que ese Soberano podrá quedar completamente servido en este particular": Count Floridablanca to J.M. González Salmón, El Pardo, 31 January 1786, AHN, Estado, leg. 4316.

114 “...componer dicho velamen viejo; que se dispondrá que de Cadiz se le remita el nuevo; pero que no lo entregue hasta recibir respuesta de Marruecos acerca de estas solicitudes voluntarias de los Arraezes de aquel Principe ... [E]l Rey desea complacerle; pero que quiere antes saber que este es su gusto para evitar equivocaciones de parte de los arraezes": Count Floridablanca to J.M. González Salmón, El Pardo, 14 February 1786, AHN, Estado, leg. 4316. 
in Algeciras there are no warehouses or any fresh supplies from which we can give him those sails. The king my master has ordered that the ones he already has be repaired, but even if repairs to the frigate should cost more than four thousand pesos fuertes, in addition to rations that come to twenty duros a day, the king my master, desirous of satisfying you, has decreed that a new set of sails be sent from Cádiz to Algeciras. ${ }^{115}$

\begin{abstract}
At about this time a letter must have arrived from the Moroccan sultan, requesting a new set of sails for the vessel. ${ }^{116}$ Eventually the Spaniards learned that the supposed threat to Captain Lubaris was a trick meant to have his ship wholly repaired for free; ${ }^{117}$ that was why the sultan should be informed of the
\end{abstract}

115 "[E]n Algeciras no hay almazenes ny ningun repuesto para poder darle dicho velamen, ha mandado el Rey mi Amo que se le componga el mismo que ella tenia y aunque passaran de Quatro mil Pesos fuertes lo que costará de reparar la Fragata, sin contar las raciones que llegan a veinte Duros diarios, el Rey mi Amo deseoso de complacer en un todo a V.M. ha mandado que de Cadiz se envie a Algeciras nuevo Velamen": J.M. González Salmón to Count Floridablanca, Darbeyda, 13 March 1786, AHN, Estado, leg. 4319. The consul also reported his receipt of a letter from Marquis of Zayas, with the news that Lubaris, "beside the new set of sails and other effects with which the frigate has been restored (and it is now better than it was)," had asked for "several other things with which to adorn the ship. Since I know what kind of people these captains are, and that if we indulge them while they are here they will make new and improper petitions every day, I am instructing the commandant to ignore every request that is not in official form; and that the moment the frigate is seaworthy the captain must be ordered to set sail for some port in these domains. If he does not do so I should be told, so that I may inform His Moroccan Majesty." Lubaris was also accused of "wishing to live with a level of ostentation and splendor that makes considerable demands on the Royal Treasury." In spite of all this "he is not pleased; this is very common among them because their character and ill-breeding allows them nothing else. It is therefore wise to remind them from time to time that they should not abuse the generous liberality with which they are treated": González Salmón to Count Floridablanca, Darbeyda, 6 April 1786, AHN, Estado, leg. 4319.

116 "...that they make him a new set of sails because the one he has is useless, and the ports of King Charles and ours are as one": translated letter from the sultan to J.M. González Salmón, 21 March 1786. The consul replied that the sultan's wishes would be respected, while letting him know of the expenses that the king of Spain was incurring: "even if the cost of repairing the frigate should be more than four thousand pesos fuertes, aside from the rations that come to twenty duros a day, the king my master, eager to please Your Majesty in everything, has ordered the new sails to be sent from Cádiz to Algeciras": González Salmón to His Moroccan Majesty, 23 March 1786, AHN, Estado, leg. 4319 .

117 Lubaris sailed from Algeciras to Salé in June 1786. He carried provisions for fifteen days and sent a letter of thanks to the Secretary of State: Count Floridablanca to J.M. González Salmón, 4 July 1786, AHN, Estado, leg. 4316. 
details "to avoid any misunderstandings on the part of the captains." 118 Lubaris also requested victuals for another Moroccan war frigate that was in Gibraltar, but was denied for two reasons:

The captain has asked that provisions be sent to the other Moroccan frigate that is in Gibraltar, of which you know from the Marquis of Zayas. He has been told that there would be no problem in supplying them if it were in one of our own ports and subject to the usual sanitary regulations.

Spanish authorities suspected that Lubaris was attempting a new deception: "There is reason to believe that the victuals the captain is requesting in Gibraltar are for selling rather than for his crew."119 Even so, the sultan conveyed his thanks to the king of Spain for the "delicate attention" and for the friendly reception that Moroccan captains received in Spanish ports. ${ }^{20}$

In 1791 Muley al-Yazid's ambassador Ibn Utman was in Madrid negotiatiating a new treaty. The sultan sent him instructions by Captain Ibrahim Lubaris, who embarked from Ceuta on 10 March in the flatboat San Antonio de Padua bound for Cádiz. A few days later the governor of Córdoba told Floridablanca of his passage through his city:

For this reason, and because he was traveling with only four other Moors, he had asked me to accompany him to [Madrid], in case of incidents.

118 J. M. González Salmón to Count Floridablanca, Darbeyda, 13 March 1786, AHN, Estado, leg. 4319.

119 "Dicho arráez ha pedido que se remitan viveres para la otra fragata marroquí que se halla en Gibraltar de que Vm tiene ya noticia por el Marques de Zayas; pero se le ha respondido que no habría dificultad en franqueárselos si estuviese en puerto nuestro y observase las reglas de sanidad que estan establecidas. ... [H]ay motivo de recelar que los viveres que pide dicho arráez en Gibraltar son para vender y no para su tripulación": Count Floridablanca to J.M. González Salmón, El Pardo, 31 January 1786, AHN, Estado, leg. 4316.

120 J. M. González Salmón to Count Floridablanca, Darbeyda, 27 February and 30 March 1786; copy of a letter from Minister Effendy to González Salmón, 13 March 1786. Perhaps the sultan's attitude arose from positive reports by Lubaris: "Captain Brahim Luberes, who arrived safely with his frigate in Larache, has been summoned by the sovereign and on the 19th of this month passed through here on his way to Court. He is exceedingly happy with the good treatment and reception he had in Algeciras all the time he was there with his frigate, and wishes to convey this to the king his master": J.M. González Salmón to Count Floridablanca, Darbeyda, 25 June 1786. The sultan wrote to the consul: "We have learned that Captain Luberes's ship is in Algeciras, and that the Spanish treat him and his crew very well, and that they are busy repairing it. All these are proofs of the true friendship between the Spaniards and ourselves": translated letter from His Moroccan Majesty to J.M. González Salmón, 13 March 1786, AHN, Estado, leg. 4319. 
I replied that I could not comply without an express order from Your Excellency, and did not know how it could be obtained; therefore with this response he left the very same day for that $[\mathrm{city}] \cdot{ }^{121}$

Lubaris was charged with giving the Moroccan ambassador both instructions for the treaty negotiations and a list of naval supplies to be obtained from the Spanish: Muley al-Yazid needed to equip several ships, including two docked at Salé. Floridablanca told the Secretary of State for the navy, Antonio Valdés, about the list

of the effects needed to equip the two ships that the king his master has in Salé, as well as some others; so you will please to look it over and tell me privately what we can give or buy to satisfy the king of Morocco, and what it will cost; for our peace negotiations are very advanced. ${ }^{122}$

Valdés replied favorably to Floridablanca's requests, but the Count proved too optimistic about the progress of the negotiations: they were soon cut off, provoking a new Spanish-Moroccan war.

Everything in the list from the ambassador of Morocco can be supplied from the shipyard in Cádiz, as long as the king approves it. But in this case either the ships to be repaired must come to Cádiz, or they must explain more clearly the measurements of the masts, sails, rigging, and other items he asks for, so they can be understood and supplied usefully and without waste. ${ }^{123}$

121 "[C]on este motivo y tener que caminar solo con quatro Moros mas me havia pedido le hacompañase a esa para las ocurrencias a lo qe le he respondi no podía servirlo sin expresa orden de V.E. que ignoraba como se pudiese tomar y con este motivo y respuesta se puso en este mismo dia en marcha para esa." He now appears in the documents as Brehem Lubares. Bartolomé Barzelar to Count Floridablanca, Córdoba, 20 March 1791, AHN, Estado, leg. 5803. On Lubaris's arrival in Cádiz from Ceuta: J.M. González Salmón to Count Floridablanca, 18 March 1791, AHN, Estado, leg. 4324.

122 “...de los efectos que se necesitan para equipar las dos embarcaciones que el Rey su Amo tiene en Salé, y para algunas otras; a fin de que V.S. se sirva verla, y me diga reservadamente lo que podremos dar o comprar para dar gusto al Rey de Marruecos, y lo que costará esto; pues tenemos muy adelantada la pacificación": Count Floridablanca to Antonio Valdés, Palacio, 1 April 1791. Palacio to Antonio Valdés, 1 April 1791, contains the same text as the former and seems to be a draft; it includes a note, "This is the list presented by the Ambassador of various effects for equipping two ships of His Moroccan Majesty's in Salé, and more for other [ships]": AHN, Estado, leg. 5803.

123 "Quanto comprehende la nota del Embaxador de Marruecos se puede facilitar del Arsenal de Cadiz, siempre que el Rey lo tenga por conveniente; pero en este caso es necesario o 
Floridablanca, under great pressure of work, wrote to Ibn Utman in almost identical language that the king of Spain had ordered

a number of naval supplies to be provided without charge ... to equip two Moroccan ships that are in Salé, with a few other items that are needed for other ships. And His Majesty, as proof that he returns the friendship that that monarch says he hopes to establish with Spain, has decided that without exception he should be provided with those naval effects from the Cádiz shipyard; for which the ships to be repaired must proceed to that port, or the measurements of the masts, sails, rigging and other items requested must be explained more clearly so they may be provided with knowledge of the need and serve usefully and without waste.

He also took the opportunity to remind Ibn Utman that "this week I will send you a note of what should be agreed so that our friendship may be a true one, useful to both monarchs and their subjects, and lasting."124

In a letter that he signed in Arabic, Ibn Utman promised to inform the sultan and said of the Spanish monarch

how grateful he makes me with this expression, which I know will please my sovereign greatly; and since Your Excellency is the instrument of moving the royal will you shall be [grateful] also for a favorable and durable peace, as I will also communicate to the king my master. The two ships for which the supplies are chiefly intended are damaged; therefore, if Your Excellency wishes to dispatch the matter quickly, you can send Captain

que las embarcaciones que han de habilitarse vengan á Cadiz, o que expliquen con mas claridad las medidas de la arboladura, velamen, jarcias y demás que pide; a fin de que se entregue con conocimiento, y puedan servirse esos pertrechos con utilidad, y sin desperdicio": note by Valdés on the margin of Floridablanca's letter, 4 April 1791, AHN, Estado, leg. 5803 .

124 “...se le franqueen varios efectos navales ... para equipar dos embarcaciones Marroquies que se hallan en Salé, con algunos otros que hacen falta á otras embarcaciones: y S.M. por una prueba de su correspondencia á la amistad que aquel Monarca le ha manifestado desea establecer con la España; ha resuelto que sin exemplar se le faciliten dichos efectos navales del arsenal de Cadiz; a cuyo fin se hace preciso que las embarcaciones que han de habilitarse pasen a aquel puerto, o que se expliquen con mas claridad las medidas de la arboladura, velamen, xarcias, y demás que se piden para que se entreguen con conocimiento y puedan servir con utilidad y desperdicio.... [L]e enviaré en esta semana una nota de lo que convendría arreglar para que nuestra amistad sea verdadera, útil a los dos monarcas y a sus súbditos, y durable": draft for Mohamet Ibn Utman, Aranjuez, 5 April 1791, AHN, Estado, leg. 5803 . 
Ibrahim Lubaris, who came with my master's commission for this business; he is well acquainted with all the measurements, and I hope Your Excellency will recommend him to the governor of that port and have him assisted as Your Excellency always does with your goodness toward every distinguished vassal of my king. ${ }^{125}$

Floridablanca told Valdés that by order of the king Captain Lubaris, "who arrived recently from Morocco with this commission, may proceed to Cádiz to arrange this matter, bearing [letters of] recommendation there." He asked to know whom the captain should approach in Cádiz, and ended on a note that suggested some doubt because of Lubaris's conduct the year before: "of course I consider it prudent that Your Excellency order a notation or copy of the enclosed list, so as to convey it to the authorities and avoid any possible abuse."126 Ibn Utman was informed that, since there were many obstacles to bringing the two Moroccan ships from Cádiz to Salé and Lubaris was the person in charge, it would be best that "some brigantine or other warship of His Majesty's go from Cadíz to Salé bearing the supplies necessary for repairing those ships in the dock where they are now, taking Lubaris aboard so that everything may be done with the necessary thoroughness and convenience."

In Cádiz the captain was to report to the Admiral of the Fleet, who had orders to give him the supplies. ${ }^{127}$ Problems arose there, however, since it was "necessary to explain the features, dimensions, etc., of each article, which no one was able to provide with the exactness required." Therefore the government insisted that it would be easiest if "those Moroccan ships came to Cádiz to be supplied with what they need; then everything can be verified without

125 “...lo agradecido que me deja con semejante exprecion qe conozco será de suma complacencia de mi Soberano; y siendo V.E. el instrumento para mober la real voluntad lo será igualmente, de una Pas bentajosa y durable como lo participare también al Rey mi Amo. Las dos embarcaciones para quienes principalmente están destinados dichos efectos se allan en casco; por lo que si fuese del agrado de V.E. acelerar como combiene este asunto podrá despachar al Arraez Brajem Lubares [sic] que bino comisionado de mi Amo para este negocio, y sabe pr extenso todas las medidas y espero que V.E. lo recomiende al Governador de dha Plaza para qe se le atienda como V.E. lo acostumbra con su bondad á hacer con todos los Basallos distinguidos de mi Rey": Ibn Utman to Count Floridablanca, Madrid, 5 April 1791, AHN, Estado, leg. 5803.

126 He asks the Minister of the Navy to tell him whom Captain Lubaris should see about his commission in Cádiz: Aranjuez to Antonio Valdés, 7 April 1791. Count Floridablanca to Antonio Valdés, Aranjuez, 7 April 1791. Draft from Aranjuez to Ibn Utman, 7 April 1791, AHN, Estado, leg. 5803 .

127 Aranjuez to Ibn Utman, AHN, Estado, leg. $5^{803}$. 
delay, and articles that do not serve the purpose will not be sent blindly while others are lacking." ${ }^{28}$

Ibn Utman was grateful that the king should order a ship to transport

the necessary effects for repairing the two ships that are in Salé, taking Captain Lubaris on board; since they know that the Admiral of the Fleet, to whom Lubaris must appeal, will have the necessary orders for carrying out what His Majesty has decreed.

He added that Lubaris understood his commission, and made a further request, noting that

this man cannot travel alone inside Spain, and I have no one to accompany him. I presume that since Your Excellency governs this country you will arrange things as you prefer so that he arrives safely, because when he came [here] he was accompanied by many people. I will be most grateful. ${ }^{129}$

Floridablanca told the Secretary of War that the king had ordered for Lubaris "two or three soldiers to escort him and one person in charge of paying his travel expenses."130 The captain made sure Floridablanca knew how much those expenses were:

128 Letter addressed to Anduaga, 12 April 1791, AHN, Estado, leg. 5803.

129 “...los efectos, que se necesitan, para abilitar las dos Embarcaciones qe se allan en Salé llebando a su bordo al Arraez Lubares: Como también que el Capitan general de la Armada a quien deberá presentarse dho Lubares, tendrá las ordenes necesarias para qe se cumpla lo que S.M. a dispuesto. ... [E]ste hombre no puede, transitar solo por España, y que yo no tengo quien baya en su compañía, estimare que gobernando V.E. este Pais lo remita del modo que guste para que llegue con seguridad, pues cuando bino fue acompañado de otras muchas gentes a lo que quedare mui agradecido": Ibn Utman to Count Floridablanca, Madrid, 13 April 1791, signed in Arabic. Also an unsigned draft note of 13 April 1791 in which the Moroccan ambassador asks for someone to travel with Lubaris to Cádiz "because he arrived here with several people who accompanied him": AHN, Estado, leg. 5803 .

130 In the margin: "To the Minister of War, I inform you so that you may please to assign the soldiers who will escort him": Aranjuez to the Count of Lerena, 16 April 1791. Lubaris would have one companion and two or three soldiers as an escort: Aranjuez to Ibn Utman, 16 April 1791. Ibn Utman expressed his gratitude: "I give Your Excellency my warmest thanks for the wisdom and insight with which you arrange things for the mutual and reciprocal happiness of our two states." He hoped for the prompt arrival of the escort "so that the captain may set out without delay or loss of time": signed in Arabic, Ibn Utman to Count Floridablanca, Madrid, 19 April 1791, AHN, Estado, leg. 5803. 
The expense he incurred in traveling from Cádiz to Madrid with documents from his sovereign to his ambassador, and in overseeing the naval equipment that Our Lord King grants to his [king], comes to 5,440 reales de vellón: 3,200 for hiring a coach and 2,240 for food, lodging, and so on. He also told me that Your Excellency will treat him and his two dependents as is customary for [Spanish] subjects of his class. ${ }^{131}$

It was duly decided that the governor of Cádiz should give Lubaris

six thousand reales, which is just a little less than what he claims to have spent in his journey to Madrid from Cádiz; plus three thousand reales to satisfy him and the two Moors who came with him. And during his stay in Cádiz he should be assigned a decent daily amount for his maintenance. ${ }^{132}$

The order was conveyed to the governor:

In addition to his having been received here with the usual attentions, and it having been decreed that an individual assigned by the Ministry of the Treasury, and two soldiers, will accompany him and pay all the expenses of his return to Cádiz, the king has resolved that by means of Your Excellency he be given one hundred doubloons to cover his trip [from Cádiz] to Madrid, and fifty doubloons to satisfy him and his two dependents, beside the decent daily sum for the time he spends in Cádiz. ${ }^{133}$

131 "[E]l gasto qe se le había originado en el viaje desde Cadiz á Madrid, á conducir a su embajador Pliegos de su Soberano, y encargase en los Pertrechos de Mar qe el Rey Nuestro Señor, á concedido al suyo que aciende a sinco mil, quatrocientos y quarenta rrs.vn. los 3200 importe del coche que alquilo, y los 2240 de la Manutencion, Posadas y demás; también me sinificó de que V.E. se dignara tenerlo presente, y a sus dos Dependientes como acostumbre con los sujetos de su clase": Francisco Pacheco to Count Floridablanca, Aranjuez, 23 April 1791, AHN, Estado, leg. 5803.

132 “...seis mil reales, que con corta diferencia ha insinuado haber gastado á su venida a Madrid desde Cadiz, y además tres mil reales por via de agasajo para el y para los dos moros que han venido con el, como también que para el tiempo que se detenga en Cadiz se le señale por el Gobernador un diario decente para su manutención": Aranjuez to Count Lerena, 25 April 1791, AHN, Estado, leg. 5803.

133 "Ademas de haber sido recibido aquí con la atención que se acostumbra, y de haberse dispuesto que le acompañe un sujeto destinado por el Ministerio de Hacienda y dos soldados haciendo todo el gasto de su regreso a Cadiz; ha resulto el Rey que se le dén por medio de V.E. cien doblones para costear el viage de venida á Madrid, y cincuenta doblones por via de agasajo para si y sus dos dependientes, además del diario decente para el 
Instructions went from Floridablanca to Antonio Valdés to the Admiral of the Fleet that the king desired a brigantine to convey to Salé

the effects they may need for repairing those ships in their present location, taking Lubaris on board so that everything can be done with the necessary precision and punctuality. That he inform the Admiral of the Fleet, to whom the said Lubaris will apply. And that he send him a copy of the [list of] items provided. ${ }^{134}$

Floridablanca received Captain Lubaris before he left Madrid for Cádiz ${ }^{135}$ and advanced him the funds for his journey. ${ }^{136}$ On his arrival in Cádiz on 4 May he took up residence in the Isla de León, ${ }^{137}$ but he presented more obstacles, as the director of the shipyard reported:

Having examined the capacity of the transport ships available in this shipyard, I inform you that, to convey to Larache the casks, anchors, and rigging described in the note Your Excellency kindly sends me, there is not one capable of carrying such a load. It could be done only after

tiempo que esté en Cadiz": Aranjuez to the governor of Cádiz, 26 April 1791, AHN, Estado, leg. 5803 .

134 “...los efectos que necesitasen para habilitar dichas embarcaciones en el parage donde están, llevando a bordo al mismo Luberes para que todo se hiciese con la exactitud y puntualidad convenientes. Que informe al Capitan General de la Armada a quien se presentará el citado Luberes. Y que le envie una copia de los efectos concedidos": Aranjuez to Antonio Valdés, 27 April 1791. Valdés alerted the Fleet Admiral in Cádiz to prepare a warship to carry the naval equipment to Morocco: Antonio Valdés to Count Floridablanca, Aranjuez, 29 April 1791, AHN, Estado, leg. 5803.

135 On Lubaris's visit to Aranjuez, where he was told "verbally many things worthy of his attention relative to this matter": Francisco Pacheco to José de Anduaga, 21 April 1791, AHN, Estado, leg. 5803 .

136 Lubaris would travel with the same man who had brought cannons from Seville, and two soldiers. "At the same time that this captain has shown himself very grateful for the way he has been treated, he has suggested through Don Francisco Pacheco (according to the attached note from the latter) that he thought he should be given 5,440 reales for the cost of his journey from Cádiz to Madrid; and that he and his two dependents should be considered for some consideration such as Your Excellency normally gives to those of his class. He has been informed that he will receive his answer in Cádiz." In this draft the writer asks if the captain's request can be granted, and that the governor of Cádiz be instructed to pay a per diem for Lubaris while he is in that city, of which the Minister of the Treasury should also be informed: draft presumably to Secretary of State, 24 April 1791, AHN, Estado, leg. 5803 .

137 Arribas Palau, "Nuevos datos sobre moros en la Alhambra," esp. 22-24. 
unloading the wood from the frigate Bibiana, and since that has not begun it cannot be ready with the speed you request and the captain requires. Therefore there is no other choice but to speed up the unloading of the Aduana, which is already well advanced; although it is a slightly smaller ship, the casks that cannot fit in its hold can go on deck, lashed to the sides. Since the errand is brief, on its return [the Aduana] can reload the wood destined for the department of Cartagena, which can be stored here in the meantime. This is all I can tell Your Excellency in view of the haste with which the captain wishes to transport these effects and the fact that he wants a single ship in which he can sail also. It is agreed that he will do the unloading with boats of the ports where he is headed, while our ship will anchor outside those ports because there is a sandbar and the entrance is shallow, so they cannot enter. ${ }^{138}$

From the Isla de León Valdés was assured that "with the proper speed and efficiency the effects requested by the Moroccan ambassador in the name of his sovereign" were being prepared. Lubaris visited the shipyard to ask that the effects be sent to Larache "because they are needed there, and because it will take time for the rest to be ready." It remained to be seen how to organize the conveyance to Larache and Salé, when at the same time the quartermaster of the fleet had to provide three hundred butts and barrels and try to find "two small warships in which to make these two shipments."139 Shortly afterward Luis de Córdoba reported that Lubaris had come to him

138 "Haviendo reconocido la capacidad de los Buques de transportes que existen en este Arsl. Para conducir a larache la Piperia Anclas y xarcias que contiene la Nota que en oficio de hoy se sirve V.E. dirigirme le hago presente no hay ninguna capaz de contener esta carga; y solo lo puede hacer después de descargar la madera la Fragata Bibiana la que no haviendola empezado aun no podrá estar pronta con la aceleración que pide y á que estrecha el Arraez por lo tanto, no queda otro arbitrio que el que se acelere la de la Aduana que la tiene tiene bastante adelantada, pues aunque es buque algo menor, la parte de pipería que no le pueda caver en la bodega la puede llevar sobre cubiertas, y arrizada á los costados y como la comisión es de corto tpo, á su regreso puede reembarcar la madera que deve llevar al Departamento de Cartagena quedando entre tanto depositada en este que es quanto tengo que exponer a V.E. en vista de la actividad con que quiere el Arraez transportar los efectos, y querer que sea un una sola embarcacion donde debe el acompañarlos haviendo quedado en que con Embarcaciones de los puertos á donde ba hara la descarga, fondeando la nuestra fuera de ellos respecto a que por se[r] de barra y tener poco fondo en la entrada, no pueden surgir dentro": Tomás Muñoz to Luis de Córdoba, Carraca, 10 May 1791, AHN, Estado, leg. 58 o3.

139 Luis de Córdoba to Antonio Valdés, Isla de León, 10 May 1791, A HN, Estado, 5803. 
claiming that, of the pulleys requested by the ambassador of Morocco, he needed and should take only two cat blocks and three iron-bound top blocks in each of the two frigates named in the royal decree of the 29th of last month.

Lubaris made further requests of the Admiral of the Fleet:

With all due respect he states that because they will not be ready for a few days, and because apart from the loads of the two frigates that will go to Salé he has to take separately to Larache the effects recorded in the attached report (these will substitute for others which appear to be ready) ... [he asks] that a vessel be chartered to be captained by a Moor who will take those effects to Larache with a letter for his sovereign, while he himself remains in order to receive the rest of the equipment which is to go to Salé.

The items in question included three hundred butts, one hundred barrels, four anchors weighing twelve quintales apiece, four twelve-inch cables, four edgeanchors with their warps, twenty lengths of canvas, twenty rolls of coiled running gear, fifty oars, and ten barrels of pitch. ${ }^{140}$

It was finally determined that the cargo should go in the Aduana, an armed urca or coastal vessel, "because only in it can the large volume of bulky equipment to be transported go at once in a single voyage; there is absolutely no other, as the attached letter states, that will do in such an urgent situation, as I have agreed." It would be unloaded first in Larache and then in Salé. ${ }^{41}$

On 20 May, with the ship already loaded, Lubaris presented new requests that had not figured in the original list: "one octant, navigation charts of the

140 “...manifestando que de la Motoneria pedida por el Señor Embaxador de Marruecos, solo combenia, y devia llevar dos Quadernales de Gata, y tres Motones de Amantes de virador herrados, para cada una de las dos Fragatas de que trata la Real orden de 29 del antecedente. ... [C]on todo respeto hace presente que en atención a que habrá de tardar algunos días el apresto de ellos y que por separado de los dos armamentos de dos Fragatas que deven llevar á Salé, tiene que que llevar por extraordinario á Larache los efectos que compreende la adjuta Relacion que deven servir para ótras, y estos al parecer están prontos": "Nota de les efectos qe además de los correspondientes a dos fragatas nuebas deven llevarse al Puerto de Larache según la orden qe el Arraez Brajim Luberiz tiene de su Amo el Emperador de Marruecos." Ibrahim Lubaris signs in Arabic writing to the Admiral of the Fleet, Isla de León, 9 May 1791, AHN, Estado, leg. 5803.

141 Luis de Córdoba to Antonio Valdés, Isla de León, 17 May 1791, AHN, Estado, leg. 5803. 
coasts of Africa and America, six large pulleys, and two tin megaphones; all of which Don Luis de Córdoba ordered given to him so that the king of Morocco would have no reason to be displeased."142

The cost of the supplies sent to Morocco was estimated at 571,827 reales de vellón: 429,009 reales and 8 3/10 maravedís in masts, sails, canvas, and rudders; 61,28 o reales in spars; 75,644 reales and 25 maravedís in butts and barrels, as well as lodging for Lubaris and his companions "in the inn called La Posada del Duque, [and the] coaches and chaises" they used in their various journeys. There were also their fare to Morocco, the octant, a spyglass, and navigation charts for America and Africa, all of it adding up to 5,894 reales. ${ }^{143}$

These attentions and payments do not seem to have aroused Lubaris's gratitude. Alcaide Driss reported that when the sultan received him in an audience in late June of that year he took the opportunity to insult the Spaniards:

Last night Captain Brahim Luberes appeared in the Menchuar courtyard on his return from Spain. He protested that His Catholic Majesty is more submissive to Muley al-Yazid than a Jew, acting as if he were his black slave. He said that all of Spain is trembling and that Charles will not only provide the equipment for the twenty ships that Muley al-Yazid is building, but will also grant him everything he asks.

Driss noted, correctly, that including such remarks about Christians was a common rhetorical practice on similar occasions. But it is strange to hear them quoted in a court whose sultans declared repeatedly that Spain was their most favored nation and its monarchs their closest friends. ${ }^{144}$

142 "A detailed report of all this will arrive, with its total value; of course I send Your Excellency for your government the reports that the sub-inspector of La Carraca shipyard has sent to me of what has been provided by him": Antonio Valdés to Count Floridablanca, Aranjuez, 24 and 27 May 1791, AHN, Estado, leg. 5803.

143 "The captain asked for the spyglass for his own use, and it was given to him"; it was worth 180 reales. Antonio Valdés to Count Floridablanca, Palacio, 7 July 1791, EHN, Estado, leg. 5803 , unnumbered.

144 "Anoche el Arraez Brahim Luberes, de vuelta de España, se presentó al Menchuar; el protestó que S. M. Catolica es más sumisa que un Judio á Muley Liezid, considerándose como un Negro suyo; dixo que toda la España tiembla, y que Carlos no solamente dará los Aparejos, \&, para las veinte Embarcaciones que Muley Liezid hace construir, sino también que le concederá quanto le pedia": J.M. González Salmón to Count Floridablanca, Cádiz, 26 July 1791, AHN, Estado, leg. 4324. 


\subsubsection{Aly Turqui and Mohamed Embarck (1786)}

Two frigates under Captains Aly Turqui and Ben Embarck sailed from Tangier for Cádiz on 11 October 1786. The Spanish consul suspected that they traveled under orders from the sultan intending "to have us repair their ships"; should the captains ask for extensive repairs he recommended "not helping them with the total reworking of those vessels unless their sovereign requests it directly from the king our master." It was, however, proper to take care of the crew and supply some equipment to the frigates:

A small attention, and they should be given anchors and ropes so that the ships do not come to grief in our own port. They have very few cables, not because His Moroccan Majesty lacks them in his warehouses in Larache and Rabat but because he prefers to get them from others, those being safer. Still, he does not realize that those will be useless because they have been so closely stored, like all the cordage and sails that the Dutch brought recently. ${ }^{145}$

A few days later the consul confirmed that the sultan had indeed sent the frigates to Cádiz for repairs: “[My] suspicion ... has just been proved true." He thought, therefore, that if the king agreed to the request

strict orders should be given to have the two frigates repaired in the shortest time possible, so that less will be spent. Let them be painted and spruced up as we did with Captain Jansaly's ship, which pleased the sovereign greatly when he saw it in Salé.

High-quality materials should be used so that there would be no cause for complaint:

Let the sails and cordage for these frigates be of the first quality, because the king of Morocco usually has [ships] inspected here and if he finds

145 “...[P] equeño agasajo, y se le suministre anclas, y gúmenas para que los Buques no se desgracien en nuestro mismo Puerto, porque ellos están mui pobres de Cavos, no porque a S. M. Marroquí le falten en los Almazenes de Larache, y Rebat, pero le agrada mas recibirlos de otros porque aquellos están seguros aunque no se hace cargo que de mui guardados bendran a quedar inútiles como sucederá con todo el cordaxe, y velamen que trageron los Holandeses últimamente": J.M. González Salmón to Count Floridablanca, Darbeyda, 14 October 1786, AHN, Estado, leg. 4319. A note on the reverse of the letter states that "BenEmbark's frigate is already in Cádiz and Señor Valdés asks what should be done, because he asks for many things and so far he has been given a cable and an anchor." 
some defect he will not be grateful for the expense we have devoted to them.

It was essential to keep the captains happy so that they would report favorably to their sultan on their reception in Spanish ports:

Blandishing and pleasing the frigate captains is worth a great deal, because they are the ones who report to the sovereign about everything. And if their persons are not treated with the deference they think they deserve, even though their mission fulfills the prince's desires they will denigrate some or nearly all of its worth. Therefore while Turqui and BenEmbarck remain in Cádiz it will be best to please them the best we can, so that later they do not give a bad report as they did after their stay in Gibraltar. ${ }^{146}$

The consul thought of Turqui and Embarck as

well-behaved men and more reasonable than others of their class whom I have dealt with. Therefore I do not doubt that they will act properly and be able to control their sailors during their entire time in Spain, so that no unpleasantness will arise.

In any event, it was essential to keep in mind that the good relations between the two monarchies must be preserved:

In our dealings with this sovereign - and you will know better than I whether his ships should be repaired - the fact is that His Moroccan

146 " $[\mathrm{C}]$ combendrá que se expidan estrechas ordenes para que dichas dos Fragatas se compongan a la maior brevedad, que es el modo de gastar menos. Que se pinten y hermoseen como se hizo con la del Harraez Jansaly, la que gustó mucho a este Soberano quando la vió en Salé. ... [Que] el velamen, y cordaje que se destine para estas Fragatas, sea de primera calidad, porque el Rey de Marruecos le suele mandar examinar aquí, y si se le encuentra algun defecto se agradecerá poco el gasto que se haga con ellas.... [E]l agasajar, y contentar a los Harraezes de las Fragatas vale mucho porque ellos son quienes informan al Soberano de todo, y si no se les hace á sus propias personas aquel obsequio á que se consideran acreedores, aunque en la Comision principal se cumpla con los deseos del Principe, ellos le quitan quando no todo mucha parte del valor, y por lo tanto será bueno que el tiempo que estén Turqui, y Ben-Embarck en Cadiz, se procure contentarlos del mejor modo que se pueda, para que no bengan después hablando mal, como hicieron quando estubieron en Gibraltar." The English had refused to repair their ships. 
Majesty is quick to anger when something he wishes done is not done; this feeling may not actually cause a rupture, but may bring about a change in the many favors done to our nation in the ports of these domains that redound to the benefit of the vassals of the king our master, and are of considerable importance.

Finally, he advised that once the repairs were finished "a drawing be made of each [vessel], placed in a glass frame and sent to me to be forwarded to the sultan."147

\subsubsection{Mate Flores (1807)}

A ship's captain named Mate Flores generated a dramatic conflict in El Ferrol, in northwestern Spain, in 1807 . He commanded the Moroccan war corvette La Suera, which docked there from 15 August to 6 September. Although the documents can be confusingly written, the incident is worth examining closely as a compendium of the problems that Moroccan captains created in Spanish ports. The dispute, a sort of cat-and-mouse game that the captain played with the governor of the port, began over payment for victuals and supplies. We owe its full documentation to the bureaucratic zeal of Brigadier Francisco

147 “...sujetos de vello trato, y de mas razón que quantos hé tratado de su clase, por lo que no dudo se comportaran bien, y savran sujetar a su Marineria todo el tiempo que estuvieren en España para que no haya el menor disgusto. ... Nuestros Negocios con este Soberano, y por lo mismo comprehenderá mejor que yo, si combiene o no repararle sus Buques, pero lo cierto es que S.M.M. se suele enojar fácilmente quando no se hace aquello que quiere, no porque transciende este sentimiento a rompimiento alguno, pero puede mui bien hacer alguna novedad sobre las muchas gracias que estan concedidas a Nuestra Nacion por los Puertos de Estos Dominios que redundan en beneficio de los Vassallos del Rey Nuestro Señor, y no dexan de ser de bastante consideración": J.M. González Salmón to Count Floridablanca, Darbeyda, 20 October 1786. The sultan wanted his two frigates "to be repaired and given what they need, also painted, with all else necessary, until they are in satisfactory condition": translated letter from the sultan to J.M. González Salmón, 17 October 1786. Admiral al-Monsor wrote to the consul in similar terms: "intending that in that shipyard they undergo all the repairs that the two frigates need, as has been done" on other occasions: al-Monsor to J.M. González Salmón, Rabat, 1 October 1786. Antonio Valdés ordered that "they be fixed with all possible speed, painting them and beautifying them as was done with Captain Hamsaly's, which pleased the sovereign greatly; and I advise you that the sails and rigging meant for those ships be of the best quality, so that in any tests they make there they may find them free of defects. Also, that you strive to please and flatter their captains and make sure that after the repairs are done and the ships painted a drawing be made of each one and placed in a frame with glass, to be sent to His Majesty's consul in Tangier so he may present them to the sovereign": Antonio Valdés to Count Floridablanca, Palacio, 26 December 1786, AHN, Estado, leg. 4319. 
de Mendieta, "Acting Military and Political Governor of this port of El Ferrol, the town of La Graña, and their district," who copied out the voluminous correspondence between the two protagonists: "I certify and attest in legal and solemn form, [witnessed by] the undersigned scribe of His Majesty and the councils of the two cities and the Board of Health in their port, that the copies of the missives of the captain of the Moroccan war corvette named La Suera and the respective replies inserted with them agree with the originals of the former and the drafts of the latter, said documents being at the present time in my possession."148 Although the letters are repetitive and their language confused it is worthwhile to analyze them as a perfect instance of the types of difficulties that Moroccan captains and envoys caused the Spanish authorities.

Mate Flores, who styled himself "Second Minister to the King," addressed the port's governor in insolent tones, reproaching him because

we are wasting our time without any profit whatsoever, when we have an order from the consulate general to enter any port in Spain to take what we need (and besides, I have orders from the Emperor to sail along this coast and that of France, and then proceed to the Channel). It is for this reason that the supplies have arrived here. Since you have insisted on keeping us detained here without supplying us, we have spent five days here without the items that we need, to wit: water, charcoal, firewood, pitch, and refreshments of meat, bread, and vegetables, and certain other things from the stores. You are not ignorant of the policy and good breeding of Spain's nobility; in other years we arrived in different ports in Spain such as Cádiz, Cartagena, and Málaga, and they did us great honor in accordance with the splendor of Spanish policy and its nobility, so I am now much astonished at the new conditions in this port. Therefore I beseech Your Excellency to give me a yes-or-no answer this very day, with a certificate signed in your own hand stating that you have not wished to give me anything. With that I will depart swiftly, for I did not come here to remain at anchor, much less to stroll through the streets of El Ferrol, not I nor anyone I have on board; only to finish my business and set sail, because you well know that the time I languish here is time when I should be at sea, and the food I consume here I will need at sea, nor can I go against the orders of my Emperor.

148 Signed by Francisco de Mendieta and the scribe Juan Antonio Cardemil, 11 September 1807. All documents are found in the "Expediente sobre los gastos ocasionados por la corbeta de guerra marroquí La Suera, arráez Mate Flores, qu estuvo en Ferrol desde el 15 de agosto hasta 6 de septiembre de 1807," AHN, Estado, leg. 4343. 
He complained that the Spanish guards assigned to his ship ("and I know who they are") had stolen several oars: "four from the boat and eight from the launch, and you know what you ought to do." He also demanded a cable, a topsail, four lengths of two-inch rope, and two lengths of canvas. ${ }^{149}$ The governor's reply makes clear that in this as in other cases, the crucial question was who would pay for the food and supplies. He found the captain's request "very strange," and would report it to the sultan of Morocco:

[A]s to the victuals, I doubt that I can approve them because of a lack of funds to purchase them. As to the cable (whose thickness you need to tell me), topsail, four lengths of two-inch rope and two lengths of canvas, they are ready to be delivered, as well as the number of casks you will need. To approve supplying the pitch, tallow, firewood, and charcoal that you request I must know the amount of each article, then I will see what the supply officer of this port can advance. ${ }^{150}$

149 “...perdiendo nosotros el tiempo sin provecho alguno siendo asi que tenemos orden del Consulado General para entrar en qualesquiera puerto de la España para tomar lo que nos hace falta (y juntamente que tengo orden del Emperador para venir por esta costa y la de Francia y luego pasar a la Canal) que por este motivo ha llegado el Bastimento haqui. Como tiene V.S. Valor que de estemos ha qui detenidos sin despacharnos pues estos son ya 5 dias que estamos aquí sin tener los Biberes qe nos hacen falta: cuyos menesteres son los siguientes: Agua. Carbon. Leña. Alquitrán y refresco de Carne pan y Berduras con otras cosas finitas de la Camara que V.S. no ignora la política y buena crianza de la Nobleza de España y siendo asi también que otros años hemos llegado ha otros Puertos diferentes de la España como Cadiz, Cartagena, Malaga y nos an echo un grande onor como manifiesta la política y Brillantes Española con su Noblesa por lo qe ahora extraño muchísimo esta novedad de este Puerto. Por lo que suplico a V.E. en este mismo dia me despache con el si ó con el no mandándome un certificado de su mano como V.S. no ha querido mandar cosa alguna y con esto me ire pronto que yo no he venido ha qui a dar fondo ni menos a pasear las calles del Ferrol ni yo ni ninguno de los tengo ha Bordo que solo mi despacho y hacerme a la Bela pues bien sabe V.S. qe este tiempo que estoy detenido luego me hase falta por la Mar, y la comida que me estoy aquí comiendo luego me hase falta por la Mar ni yo tampoco puedo ir contra las ordenes de mi Emperador": "1 $1^{\circ}$ Oficio de Mate Flores al Gobernador de El Ferrol," 15-18 August 1807, AHN, Estado, leg. 4343.

150 "[E]n quanto a los viveres dudo poder verificarlo por falta de caudales para su compra: por lo que mira al Cable (cuyo grueso necesito me diga) Belacho de Popa quatro rollos de cuerda de dos pulgadas y dos piesas de Lona están prontas a entregarse como también el numero de piperia que debía recorrerse. Para poder verificar la entrega del Alquitran, Sebo, y Leña y Carbon que V. solicita necesito saber la cantidad de cada articulo y veré lo que pueda franquear el Sr. Yntendente de Marina de este Departamento": Governor to Flores, 19 August 1807, AHN, Estado, leg. 4343. 
He concluded by declaring that the ship's delay in port was none of his doing, since such decisions were made by the Admiral of the Kingdom of Galicia, but that he was investigating the theft of the oars. The Moroccan captain replied in more moderate tones than before, declaring himself "highly gratified" and begging the governor not to be offended - but also seizing the chance to make new demands. He believed that the dispute originated in the orders he had received from the sultan, "who allows me no more than three or four days in any port, whereas I have been anchored here for six; and it would grieve me sorely to anger my Emperor and break the promise I made to him." He apologized for not having dated his letter, since "we have no calendar here," and specified that the cable in question should be fourteen inches thick. At the same time he asked for "a twenty-four-inch signaling flag for seventeen signals and another for sixty signals; two arrobas of charcoal, two arrobas of linseed oil, [and] twenty-five pounds of lampblack."151

In another missive the captain offered a list of his basic needs: one hundred quintales of firewood, forty arrobas of charcoal, eight arrobas of tallow, two barrels of pitch, twenty buckets, twenty-four oars, twenty-four bailing sacks, and twelve shoulder-carried barrels. He insisted that he meant to sail as soon as possible, in three days at the most:

[I]f you do not supply me within three days, then just give me water and wood and I will set sail, for I have no order from my Emperor to stay in port more than two or three days. Otherwise, please give me a paper [saying] that I have received nothing, that I wish to sail if you allow me only wood and charcoal and I will be satisfied, and with that paper I will write nothing after this. ${ }^{152}$

The governor explained how difficult it was to provide what the captain wanted - but that it could be obtained at once "if you buy [it] with your own money":

If from the very first day you had requested the items you needed from the shipyard, specifying their dimensions, quantities, and number, you would already have them aboard and you could have sailed. But not only

\footnotetext{
151 Mate Flores to the governor, 19 August 1807, AHN, Estado, leg. 4343.

152 "[S]i acaso dentro de tres días no me despacha: darme agua y leña no mas y me hago á la vela; pues no tengo orden de mi Emperador de estar mas en puerto que son dos ó tres días, y de lo contrario mande V.s. un papel qe yo no he recibido nada, qe me quiero haser a la vela mandándome que solo leña y carbón y con esto me basta y con el papel no escribo mas papel otro que este": Undated letter, AHN, Estado, leg. 4343.
} 
did you not do this, rather you have asked for many articles every day. ... Last night I received your third paper, in which you tell me the thickness of the cable, ask for two arrobas of soap, two of linseed oil, twenty-five pounds of lampblack, a standard, and a flag, with their dimensions. ... As for refreshments and victuals, I am awaiting the order of His Excellency the Admiral of the Kingdom because I am unable to provide them; but if you wish to buy them with your own money we will find the way to approve them..$^{153}$

Mate Flores confessed that he had no "interests" that would allow him to buy the supplies, which had been allowed him in other ports without payment. He also claimed that on his first day in port he had needed only water, charcoal, wood, pitch, and ropes, but that as time passed his needs had increased:

You tell me that every day I appeal to you with some thing or commission. And I tell you that other people under my command are the ones who ask me to do it, and that this or that item is lacking, and tomorrow I will need it at sea. And they will say that I was in El Ferrol, and why did I not request what I needed? And I greatly fear that my king will say the same when he asks me. Therefore I say to you that when you tell me that refreshments and victuals can be had if I have money to pay for them, I reply that on other occasions we have docked in other ports that supplied everything without demanding "interests." I was persuaded that in El Ferrol it would be the same, and therefore I did not try to bring interests for buying things. Above all, if I tell my king about this he will not want to believe that I have been treated like this in a port in Spain. ${ }^{154}$

153 "Si desde el primer dia hubiera V. pedido los efectos de Arsenal que necesitava expresando sus dimensiones cantidades ó numero ya los tendría a bordo y podría haber dado la vela, pero no solo no lo ha hecho Vm. asi sino que cada dia solicita muchos artículos.... Anoche recibi el tercer papel de V. que me dice el grueso del cable, pide nuevamente dos arrovas de Jabon, dos de Aceite de linaza, veinticinco libras de negro humo, una Bandera y un gallardete con sus dimensiones. ... En quanto a refresco y viveres espero la orden del Exmo. Señor Capitán General del Reyno pues me hallo sin facultades para ello, pero si V. quiere comprarlos por su dinero se le facilitará el modo de verificarlo": Undated letter, AHN, Estado, leg. 4343 .

154 "V.S. me manda a decir que cada dia le boy con una cosa ó embaxada le digo ha V.S. que estos otros que estan debajo del comando mio son los que dicen que mande y que hase falta esto y esto y mañana me hara falta por la mar y me diran que estube en el Ferrol, por que no pedi lo que me hacia falta y me da mucho miedo también quando mi Rey me lo pregunte me dira lo mismo: por esto lo entero a V.S. me manda a decir del refresco ó Biveres que si tengo con que comprarlos se pueden facilitar le digo a V.S. si como en otras 
The governor's reply stressed once again that the captain's requests had lacked detail and were always followed by new demands:

Today you give me the dimensions of the topsail and the coils of rope, and tell me that the two lengths of canvas are for topgallants. But you do not provide the lengths of the coils of rope, nor say if the oars are for launches or boats, or the length of the fourteen-inch cable. ... I am also waiting for you to tell me if the cows should be slaughtered or alive, and I send you a dozen brooms. ... We will order the firewood in La Graña, but not the tallow or the charcoal since neither of these is found either in the warehouse or in town. ${ }^{155}$

Mate Flores offered the excuse that some of the requests had come not from him but from his interpreter. He made a few specifications:

As for the length of the rope, I tell you that there is no need to state the length because no rope can be measured; and you know that it is for fastening the spare anchor... The oars are for the boat and the launch, and I do not say if they are for the boat; I tell you [I need] eight oars of six and a half "English" measure and sixteen of five and a half "English" measure. ... I will be given firewood in La Graña but I do not know what the word "Graña" means. As to the rest, the tallow and charcoal are very specific things to be ordered because I have none on board. When you ask me about whether the cows should be alive or dead I tell you that I said nothing about this nor do I need to buy them; it is the interpreter who included all this. If I am forced to spend more time here then I request for me and my people that tomorrow you send me without fail four

ocasiones que hemos yegado a otros puertos han facilitado todo sin mediar intereses me persuado que en un Señor Ferrol como este me seria lo mismo por esto mismo no he procurado el traer intereses para comprarlos y sobre todo que esta es una cosa que si la digo a mi Rey tampoco me querra dar crédito que en un Puerto de la España me haigan hecho asi": $3^{\circ}$ oficio de Mate Flores, 20 August 1807, AHN, Estado, leg. 4343.

155 "[H] oy me incluye la dimensión del Velacho de Popa, rollos de cuerda y dice que las dos piezas de Lona son para Juanetes pero no advierte el largo de los rollos de cuerda ni si los remos son para Lanchas ó Bote y el largo que debe el Cable de 14 pulgadas de grueso.... Asimismo espero me diga V. si las reses han de ser muertas ó vivas y remito una docena de Escobas. ... La leña se encargará en La Graña pero no el sebo ni carbón por no haberlo en la Provision ni en la Villa": Governor to Mate Flores, 20 August 1807, AHN, Estado, leg. 4343 . 
snatch-blocks with three eyes [apiece] and four dead-eyes with thick, three-strand rope. ${ }^{156}$

The governor responded that when the topsail was ready it would be brought aboard the corvette with the other supplies, and asked "if the standard and the flag should be those of Morocco or of another power." He announced that the next day the captain would be provided with "the one hundred quintales of firewood from the warehouse at La Graña, from which the water has been taken during these days." 157

Mate Flores expressed himself "grateful for your generosity," though he still complained about the slowness of the provisioning. He specified that the standard and the flag should both be those of Morocco, and did not fail to add some new requests:

I would be happy if you would send me together with the firewood a bit of pitch, because do not have enough aboard even for one piece of ropefiber. I inform you that I have no more paper, wafers, ink, or pens, so I will be grateful if you send some to me with your next letter. I thank you for considering this small inconvenience. ${ }^{158}$

In his next letter the captain acknowledged with thanks the delivery of two arrobas of soap, a dozen brooms, and a supply of cabbages. And he presented still more demands, which supposedly came from the sultan:

156 "[L]a largura que ha de tener el Cable le digo a V.S. que no se necesita poner la largura pues ningun cable se puede contar pues el dicho Cabo no lo ignora V.S. que es para amarrar la esperanza ... los remos son del Bote y la lancha qe no le mando a decir si son para el Bote le digo a V.S. 8 remos de 6 1/2 reglas a la Ynglesa y 16 remos de $5^{1 / 2}$ reglas a la Ynglesa... la leña se me entregará en La Graña no entiendo una palabra de Graña que significa, de los demás el Sebo y Carbon son cosas muy precisas el mandarla pues no tengo nada á Bordo de lo que me dice V.S. de las reses si han de ser vibas ó muertas le digo a V.S. que yo no ablado nada de eso ni lo necesito comprar pues quien ha impuesto todo esto es el intrerpete. Si acaso he de sentar haqui mas tiempo entonses yo lo pediré para mi y para la gente me mandará V.S. mañana sin falta 4 pastecas De 3 ojos y 4 vigotas de Cabo gordo de proa largas de 3 canales": Mate Flores to the governor, $4^{\circ}$ Oficio, 20 August 1807, AHN, Estado leg. 4343 .

157 Governor to Mate Flores, 21 August 1807, AHN, Estado, leg. 4343.

$15^{8}$ "Estimaria que V.S. me mandase con la Leña un poco de Alquitran que no tenemos á Bordo siquiera un poco para darle a una filastua. Le hago presente a V.S. que no me ha quedado papel ninguno ni oblea ni tinta ni plumas por lo que me estimaré V.S. me las mande en el primer oficio que mande. Quedo mui agradecido de V.S. considerando el poco de molestia": Mate Flores to the governor, $5^{\circ}$ Oficio, 21 August 1807, AHN, Estado, leg. 4343 . 
Please see how to obtain the sacks and shoulder-borne barrels, for we have none on board. The coal you mention should not be of ore, for that is no good to me. And because we are ordered by the emperor of Morocco not to spend more than three days in port, consider that you must send me food every day, because what I have on board is not enough, and I should be glad of it. Know that I still have not received anything of all I have asked of you, except for the soap, the brooms, and these few cabbages. Therefore I ask you to send me the pitch, because all the rope-ends I have on board are unraveling. ${ }^{159}$

In his next missive the captain complained of how slowly the supplies were arriving:

I do not understand how you are causing me this delay in my provisioning, since you know how kings issue orders for things that must be done without fail. I hope that you will send the the rations for these fifteen days that I have been delayed here, because I will need all of it immediately at sea; and you must be responsible for all of the above. We have spent twelve days in this port and will need to spend three more, which makes fifteen. You shall send two quintales of tallow and eight pounds of bombnails and two leather holders with six dozen small and large needles for sewing the sail. Of the two dozen oars that I requested you have sent only eighteen and I asked for twenty-four, in addition to the twelve that were stolen. You will send this that I am still to receive, together with the firewood, with the greatest haste. ${ }^{160}$

159 "[L]os Sacos y Barriles de hombro mire V.S. como el remediarlo pues no tenemos ninguno a bordo. Del Carbon que dice V.S. no lo mande de piedra pues no me aprobecha de nada y siendo asi que tenemos orden del emperador de Marruecos para no estar en puerto mas que 3 dias considere: V.S. qe es menester mande la Comida todos los días pues no me vasta la que tengo a bordo; y yo también lo estimaré mucho sepa V.S que todabía no he recibido nada de todo lo que le manda a pedir a V.S. que solo el Jabon las Escobas y este poco de refresco de Coles por lo que quedaré V.S. me mande el alquitran pues todos los cabos que tengo a Bordo se me estan Rovando": 60 Oficio from Mate Flores to the governor, 22 August 1807, AHN, Estado, leg. 4343.

16o "[N]o se como puede ser: que V.S. me haga esta tardanza en el mio despacho sabiendo V.S. las ordenes que pasan entre los Reyes que es menester haser o que mandan sin faltar ni un punto, estimare de V.S. me mande la racion de estos 15 dias que me tiene detenido aquí pues todo esto luego me hace falta por la Mar, como también es menester que se haga cargo V.S. de lo sobredicho= Son 12 dias que estamos aquí en el Puerto y tres que nos quedan que estar que con 15 dias; mandará V.S. dos quintales de sebo y ocho libras de clabo de Bonba con dos queros con 6 docenas de Abujas chicas y grandes para coser la vela de las dos dozenas de remos que le mande a pedir a V.S. no me mando mas que son 
In answering the captain's three most recent missives the governor placed the blame for the delays on the Moroccan, because if

on your arrival you had given me a list of all the effects you needed with their measurements, quantities, and weights, of course they would have been supplied. ... The same is true now with the fifteen days of rations that you asked for yesterday, without naming the kinds and quantities you wish; for since some nations use certain measures and some use others, you need to specify them.... In my report to His Excellency I asked for twenty-four oars, and if only eighteen have been issued it is a mistake by the shipyard. As for the twelve oars that you claim were stolen from the corvette, that matter is pending before His Excellency. There is no melted tallow, but if you can use it in the form of candles I will send them. I will renew the request for the bomb-nails, two leather holders, and the six dozen small and large needles that you mention in your latest letter. ${ }^{161}$

The captain's eighth letter expressed his frustration, since he believed that he should not be dealing with the brigadier at all:

In all the other ports where we have docked we have been supplied by an officer other than the Governor of the city; but now I have no one but you to provide what is necessary in this port, only you and what you tell me about the rations. When you ask me to tell you what I want, I tell you to order them just as the King of Spain grants to his subjects: know that I have on board one hundred seventy-five old and young men in all, including fifteen officers. Do not send salt pork or wine, but equal amounts of suet, which must not be from pork. I undertand the matter of the oars.

18 y yo pedi 24 hafueras de $12=$ que me han robado mandara V.S. con la mayor brevedad esto que me queda que recibir con la leña": $7^{\circ}$ Oficio from Mate Flores to the governor, 25 August 1807, AHN, Estado, leg. 4343.

161 "[Si] desde su arrivo me hubiera pasado una lista de todos los efectos que necesitaba con sus dimensiones, cantidades y peso, desde luego se le hubieran proporcionado.... Lo mismo sucede en el dia con las raciones que pide con fecha de ayer para 15 dias sin expresar los generos y cantidades de que las quiere, pues como unas naciones usan de una especie y otras de otra, es preciso expresarlas. ... En la noticia que pasé a S.E. pedi 24 remos y si no se han remitido mas que 18 ha sido equivocación del Arsenal, y en quanto a los 12 remos que dice le robaron de la Corveta es asunto pendiente ante S.E. No se halla sebo derretido, y si le puede servir hecho velas lo remitiré y pediré nuevamente las ocho libras de clavo de Bomba, dos Cueros y las 6 docenas de Agujas chicas y grandes como me dice en su citado ultimo oficio": Governor to Mate Flores, 26 August 1807, AHN, Estado, leg. 4343 . 
I have greater need of the tallow, because I have none for greasing the rope-ends; you can send it as candles or as you wish because it is not meant for eating. You will also send a boom for the poop measuring twenty reglas of twenty-four inches, and a yard for a studding-sail measuring twelve and a half reglas. ${ }^{162}$

Mate Flores pressed even harder in his ninth letter, now asking for

the canvas buckets, because I need them the most; also two pumps, one for oil and one for water. And you will send two pounds of small bombnails. I trust that you will oblige me by finding an artisan who will clean two watches, paying what they are worth; and if you tell me so, I will send them to you. You will send two dozen fishhooks with their thimbles, and another two dozen large and small thimbles, and two dozen woven baskets for shifting ballast. ${ }^{163}$

He repeated his petitions (while claiming there would be "no more for now") in the tenth missive, which also expressed his gratitude and the conviction that supplying his ship was important for both nations:

These activities are necessary for the crowns of our kings. I expect no other favor from you, but send two barrels of suet, for I need nothing more and we wish nothing else. ... You will send a piece of slate with a

162 "[E]n todos los Puertos que hemos arrivado ... emos tenido otro suministrador qe nos suministre que el Sor. Gobernador de la ciudad por lo que no tengo agora otro que V.S. que suministre lo que hase falta en este puerto que solo V.S. de lo que dice V.S. de las raciones que le exprese que es lo que quiero le digo a V.S. que las mande según las pasa el Rey de España ha su gente enterándose V.S. que son a Bordo ciento y setenta y 5 ombres Grandes y chicos en todo contando 15 oficiales. Del Tosino y vino no mande V.S. pues su valor lo puede mandar en manteca y que no sea del puerco: de los remos soy enterado el sebo me hace mayor falta que no tengo para untar los Cabos los puede mandar a velas o de lo que le pareciere pues no es para comer, mandara V.S. una Bota Bara de la Popa de 20 reglas de 24 pulgadas y un palo de harrastradera de dose reglas y media": $8^{\circ}$ Oficio from Mate Flores to the governor, 26 August 1807, AHN, Estado, leg. 4343 .

163 “...los Baldes pues me hacen mayor falta con dos Bombas una para el aceite y otra para el agua y mandara V.S. dos libras de clavos de Bombas chiquitos: me estimaré que V.S. me haga el fabor de ver algun maestro que me limpie dos reloges pagando su valor: y si me los manda ha desir se los mandaré mandara V.S. dos docenas de Ganchos con sus guarda cabos con otras dos docenas de guardacabos chicos con grandes dos docenas de Espuertas para tomar al lastre": $9^{\circ}$ Oficio from the captain to the governor, 28 August 1807, AHN, Estado, 4343 . 
wooden edge for writing. No more for now, and let this suffice for a final favor. ${ }^{164}$

The governor assured the captain that his requests were receiving attention, but rejected the offer of the watches (which were probably corsair booty):

Since we have in our warehouse no beef suet to replace the salt pork and wine from your ration, we will provide you the same amount of salt meat or rice, as you prefer. ... You know how readily up until now you have been given whatever you asked for and found in this shipyard, and I hope that you will cease verifying every detail but will ask once and for all for what you need, on the assumption that it will be given to you if it can be found in this department. I repeat once again that if from the first day you had presented an account of all you required, with measurements and weights, it would have been supplied at once, so that cannot serve as an excuse for your delay. You need not send me the watches because I cannot receive them while you are under quarantine, on which point I will write to His Excellency the Admiral of the kingdom. This does not prevent you from sailing at the first convenient time. ${ }^{165}$

Mate Flores, imperturbable, returned a request for further equipment:

Send the baskets, fishhooks, and their thimbles, as well as the boom with its hook and the studding-sail for the mainmast, with the supply of rice and salt meat. I will not tarry in this port, and this is all I need in order to

164 “...estas diligencias que son precisas a las Coronas de nuestros Reyes no espero de V.S. otro favor de mande V.S. dos barriles de manteca que no necesito otra cosa y ya no queremos mas nada. ... [M]andará V.S. una piedra de mar para escribir con el margen listonado de madera no mas por agora y baste por ultimo fabor": $10^{\circ}$ Oficio from the captain to the governor, 28 August 1807, AHN, Estado, leg. 4343.

165 "No habiendo en esta Provision Manteca de Baca para suplir la parte de vino y tocino de la racion, se le suministrará a V. esta en carne salada ó arroz según le parezca. ... Sabe V. con la franqueza que hasta el dia se le ha dado quanto ha pedido y encontrado en este Arsenal y espero no continue en verificarlo por menudo pidiendo de una vez lo que necesite en el supuesto de que se le dará si se hallase en este Departamento. Buelbo a repetir a V. si desde el 1er dia hubiera puesto una relación de quanto necesitava con sus medidas y pesos se le hubiera franqueado inmediatamente sin que esso pueda servirle de disculpa en su detención. No tiene Vm. que enviarme los Reloxes pues no puedo adquirirlos mientras se halle en Quarentena sobre cuyo punto escribo al Exmo.Sr.General del reyno sin que esto obste a que pueda dar la vela quanto lo tenga por conveniente": Reply from the governor, El Ferrol, 28 August 1807, AHN, Estado, leg. 4343. 
sail. The brooms you sent the other day have already broken, so I tell you that you may send another two dozen. 166

At this point the governor resorted to quoting the regulations on how warships from Spain and Morocco should be received in ports of the other country. Specifically, he sent an exact copy of Article 23 of the Treaty of 1799:

In every equipped port in Spain, Moroccan warships shall be admitted according to the precautions and formalities established by the health authorities for the safety of public health. In case of shipwreck or forced safe arrival at any bay that is not usually equipped, all possible assistance will be given to save persons, ships, and effects; this work shall be compensated at current prices, as well as the value of any provisions they purchase, without charging duties of any kind, nor on any merchandise that is salvaged and is to be shipped elsewhere. Only if goods are to be sold inside the country will the usual duties be imposed. Reciprocity for the same will be observed for Spanish warships, without any distinction, in the coasts, bays, and ports of His Moroccan Majesty.

He added that he had provided everything that was requested and that could be found in the shipyard and the naval supply yard:

For my part (in the absence of any consul or agent of your nation, and since you were without funds) I have given you all the other effects that appear on your receipt. And if on your arrival in this port on the 15th of this month you had made a single list of the articles you needed with their measurements, weights, and qualities, you would not have needed to remain more than the three days that, according to your earlier missives, your Emperor allows you. Therefore your long delay is a claim that your sovereign can make against you, while I will bring it to the notice of my superiors.

This shipment includes no chickens or fresh meat to replace the rations of wine and salt pork; you can only replace these with rice or salt meat, as I told you before.

166 "[M]ande las Espuertas y los Ganchos y los Guarda Cabos, y la Bota vara con su gancho y el Botalon de la mayor con la Provision de la Ros y carne salada no me dilato en este Puerto que solo por esto que me hace y hacerme ha la vela. Las escobas que mandó V.S. el otro dia ya se han rompido por lo que le digo a V.S. que puede mandar otras dos docenas": $11^{\circ}$ Oficio from the captain to the governor, 30 August 1807, AHN, Estado, leg. 4343. 
The boom is ready, and you only need to say if it is the type with a hook or with a fork; when you advise of this it will be sent you with the other items you requested yesterday, except for the buckets, which are also not found in this shipyard.

I trust that now you are equipped with everything that you asked for and can be found in this port you will be prepared to fulfill the orders that you say you have from His Moroccan Majesty. ${ }^{167}$

Not surprisingly, the captain responded with a twelfth letter: he had entered the port for a mere four days, and the brigadier should know

that when a vessel sails the sea and arrives at some port, it is only for lack of a sail or other items; we are working and are in the habit of requesting what we need. In our own lands we do the same when there is a ship of His Catholic Majesty: when it lacks something we supply what they ask. Therefore, please forgive the trouble we have given you every day when we ask for what we lack: as of today we have been here for eighteen days

167 "En todos los Puertos habilitados de España se admitirán los Buques Marroquies precediendo las precauciones y formalidades establecidas por la sanidad para la seguridad de la Salud publica. En caso de naufragio ú de arrivada forzozo á qualquiera rada en horabuena no esté generalmente habilitada se le asistirá haciendo lo posible para libertar personas, Buques y efectos; cuio trabajo se satisfará a los precios corrientes asi como el valor de las Provisiones que compren sin exigir derecho de ninguna clase ni tampoco de las mercaderías que se salven y se quieran conducir á otra parte; pues solo quando se hubiesen de bender en el Pais se cobrarán los establecidos. La misma reciprocidad se observará sin la menor diferencia en las costas, radas y Puertos de S.M.Marroqui con los Buques Españoles. ... [P]or mi parte (por falta de Consul ó agente de su Nacion y no hallarse V. con caudales) le he facilitado los demás efectos que constan por su recibo, y si desde su arrivo a este Puerto que fue el 15 del corriente hubiera pedido por una relación sola los artículos que necesitava con sus dimensiones, pesos y calidades, no hubiera tenido que detenerse mas que los tres días que según sus anteriores oficios le permite su Emperador, y pr consiguiente su dilatada demora es un cargo que podrá hacerle su soberano pues por mi parte lo haré presente a la Superioridad para qe llegue a su noticia.

"Esta Provision no tiene Gallinas ni carne fresca que dar en lugar de las raciones de vino y tocino y solo podrá verificarlo en arroz o carne salada como tengo hecho decir a V. anteriormente.

"Está pronta la Botavara y solo falta diga V. si ha de ser de gancho ú orquilla y con su aviso se remitirá con lo demás que pidió ayer excepto los Baldes que tampoco se hallan en este Arsenal.

"Espero que hallándose ya surtido de quanto ha pedido y se ha hallado en este Puerto estará pronto a cumplir con las ordenes qe expresa tener de S.M.Marroqui": "Contextacion del Gobernador al anterior oficio y a lo que de palabra le dijo el Ayundante del Capitan del Puerto de parte del expresado capitán," 30 August 1807, AGN, Estado, leg. 4343. 
and have not yet taken on our water. Also, you have not sent the boom and the other things we have requested such as the hooks and thimbles, and now we need you to send fifteen days' worth of additional rations, since we will be sailing and do not know what we will need. You will also send two more barrels of pitch, since what you sent is finished. It is also true that we are brothers in God and we do not know when we can leave; if it were our pleasure we would have left already. And now we hope that you will order what we need and have asked for; yesterday you said that you could replace the salt pork and wine with rice and salt meat, a favor I hope you will do in the name of God. As for when you tell me in today's letter that I am enjoying being here, consider that I am not some merchant who has come to trade; for I value one month at sea more than one day here in quarantine, and I would rather be a prisoner on land than here [on board], because on land I would be seeing people and would be better off. Therefore I ask you only for the food for the king's people and for what the king's ship needs. We are looking into what we lack from land, and waiting for the reply, whether you wish to send it or not; if you wish it then sign below, and if you wish to send nothing then I will depart satisfied and happy. Your way of treating us is not done even to the Jews in Spain, because just as if we were in quarantine our boat cannot leave the dock. How can you dare to say that I want to remain here in port, with a command like the one I have from my king? For this very reason you must send the paper about my delay, for once you have detained me here because of your king, you have to give me a certificate for my king [to explain] my tardiness. ${ }^{168}$

168 “...que un Bastimento que va por la Mar y arriva algun puerto solo es por falta de alguna vela o algunas otras cosas pues estamos trabajando y vamos pidiendo según nos va faltando pues en nuestras tierras hasemos lo mismo quando hay algun Bastimento de la S.M.C. pues según le va faltando nosotros le vamos suministrando lo que piden y asi V.S. perdone por la molestia que le molestamos todos los días pidiéndole lo que nos hace falta oy son 18 dias que estamos aquí y todavía no hemos hecho el agua: también la Botavara no ha mandado V.S. y lo demás que se le ha pedido como los Ganchos y Guardacabos y agora nos hase falta que V.S. mande 15 dias de raciones otros: pues nos vamos ha la Mar y no sabemos si nos hara falta: mandara V.S. otros dos Barriles de Alquitran pues el que mando se ha dado el fin, también es cierto que somos hermanos de Dios y no sabemos quando salimos afuera si fuera nuestro gusto ya hubiéramos salido y agora esperamos mande V.S. esto que nos hase falta y que hemos mandado a pedir, el Tozino y el vino que dice V.S. lo puede mandar en arros y carne salada qe dijo ayer; favor que espero de V.S. lo haga por Dios, de lo que me dice V.S. en el contenido de hoy qe yo tengo gusto destarme aquí en Badia considere V.S. que yo no soy ningun mercante qe hemos venido a negociar que mas me estimo un mes por la mar que un dia haqi en 
The governor's reply accused the captain of remaining in port of his own free will:

I have told you that in this shipyard there is no manufacture of buckets, nor are there any in town; nor any woven baskets either, because those come from the Mediterranean where esparto grass is grown. But through my continuing good will I will send you the salt and the brooms that you ask for again, assuring you that this is the last time I will attend to your requests. All of them would have been granted to you from the beginning if you had asked for them methodically according to the rules, as I have told you in my previous letters. ${ }^{169}$

In a subsequent missive the governor told the captain that

this afternoon the effects that you have asked for and can be found will be taken on board, time permitting. And tomorrow we will order from the warehouse in La Graña the provisions you have requested. When you are prepared to sail I will give you the certificate that you claim to need for your affairs. ${ }^{170}$

quarentena mejor estuviera estar pricionero en tierra que no estar aquí pues en tierra estaría mirando la gente y estaría con mas gusto y asi yo no le pido otra cosa a V.S. que la comida para mi Gente de Rey y lo que le falta al Barco de Rey estamos mirando lo que falta de tierra esperando la respuesta si quiere mandar: esto o no y sino quiere mande y firme abajo que no quiere mandar nada y me ire gustoso y contento: este modo qe V.S. nos trata no se hace ni con los Judios en España pues lo mismo que la quarentena que no se puede el Bote nuestro alargar del costado pues como tiene V.S. valor de decir que yo quiero sentar haqui en puerto como una orden de mi Rey como la que tengo que por esto mismo es menester que V.S. mande el papel de la mia tardaza pues una Bes que ustedes me detienen haqi por el Rey también V.S. es menester que me de un certificado para mi Rey por la mia tardanza": $12^{\circ}$ Oficio from the captain to the governor, $3_{1}^{1}$ August 1807, AHN, Estado, 4343 .

169 "Tengo dicho en este Arsenal no hay fabrica de Baldes ni se encuentran en el Pueblo, como tampoco espuertas pues vienen del Mediterráneo donde está el esparto. Pero siguiendo mi constante buena armonía le remitiré la sal y escobas que nuevamente me pide asegurándole será la ultima vez que atenderé a sus peticiones, pues todas las posibles se le hubieran franqueado desde el principio si las hubiera solicitado con método y regla como le tengo dicho en mis anteriores": Reply by the governor, 31 August 1807, AHN, Estado, leg. 4343 .

170 "[S]e le conducirán esta tarde a bordo los efectos que tiene pedidos y se han hallado, si el tiempo lo permite, y mañana se le encargaran en la Provision de la Graña las raciones que ha solicitado, y quando determine hacerse a la Vela le remitiré la certificación que pretende V. arreglada a sus oficios": Governor to the captain, 1 September 1807, AHN, Estado, leg. 4343 . 
At last, the governor of El Ferrol could inform his superior that the Moroccan corvette had put to sea on 6 September 1807. He sent him copies of Mate Flores's letters, insisting that the captain's "delay in this port was voluntary, as is clear from these documents"; and he asked that the superior, "once advised of them," inform the sultan of the captain's "lack of respect toward a Governor of His Catholic Majesty." He reported that the local Admiral of maritime affairs had provided "whatever articles were requested and could be found in this shipyard," and that all would have gone better if the captain had expressed his needs "on his arrival, with information about their size, quality, and weight." The governor had had to assume the expense of everything the captain was given,

because the Emperor has no consul or agent of his nation in this port nor had the captain funds to pay for the items he requested, which are listed under number 3 . And since mutual harmony between the two powers is recommended by the royal decree of 17 February 1766 and the peace treaty of 1 March 1799, I have been forced to pay for them myself. In this port and in its board of health there are no funds for chartering the boat that we needed to replace the board's supply launch: it was detailed to the ship by order of the Royal Navy, because [the Moroccan vessel] could not leave its mooring during the nineteen days under observation because of quarantine, on the decision of that board with Your Excellency's approval. That gentleman told me that he could offer only the shipyard's launch, but not the boat, to ferry the guards back and forth. [Then there were] the meals and other items that arose, the whole reaching a total of 2,245 reales and 28 maravedís, a sum that I hope His Majesty will order repaid from the Royal Treasury. ${ }^{171}$

171 “...con motibo de que el Emperador no tiene en este Puerto Consul, ó Agente de su Nacion, ni el Capitan caudales con que pagar los efectos que ha pedido por separado, los que constan en el $\mathrm{n}^{\circ} 3$ y como por otra parte está tan recomendada la buena reciproca armonía entre ambas Potencias por Real orden de 17 de febrero de 1766 y por el tratado de paz de $1^{\circ}$ de marzo de 1799 , me he visto precisado á satisfacerlos por mi por no haber fondos en esta Plaza, ni en la junta de Sanidad de ella para el pago del flete del Bote que fue preciso tomar para el servicio de la Lancha esquifada de Sanidad que se le puso por la Rl.Marina, y no poder esta separarse de su apostadero respecto a haber estado 19 dias en quarentena de observación por disposición de dicha Junta aprobada por V.E. pues aquel Señor Exmo me dijo que solo le correspondia dar la lancha del Arsenal pero no el Bote para llevar y traer la Guardia, comidas y demás que pudiera ofrecerse ascendiendo el todo a 2245 rrs y 28 mrs., cuia cantidad espero que S.M. dispondrá se satisfaga por la Rl. Hacienda": Francisco de Mendieta to Francisco Taranco, El Ferrol, 17 September 1807, AHN, Estado, leg. 4343 . 
The final accounting was as follows: ${ }^{172} 24,968$ reales and 27 maravedís for the repair and restoration of the corvette, ${ }^{173}$ plus 14,399 reales and 7 maravedís for victuals and provisions. ${ }^{174}$ To those must be added the costs of transporting

172 "Relacion de los efectos que se facilitaron de estos Reales Arsenales para la avilitacion de la Corveta de guerra Marroqui nombrada la Suera su capitán Mate Flores, y de los Viveres, y demás Articulos que recivio de la Provision de Marina de este Departamento, con expresión del valor parcial, y general a saber": El Ferrol, 17 September 1807, AHN, Estado, leg. 4343 .

173 The ship was supplied with: "eighteen 13-foot oars (315 reales); eighteen 12-foot oars (315 reales); four 11-inch dead-eyes ( 32 reales); four 26 -inch snatch-blocks, each with three ropes (106 reales); one 14-inch cable, 120 brazas [arm-spans] long, weighing 3,68o pounds (14,6o9 reales); four hundred eighty brazas of 2 -inch tarred rope weighing 360 pounds $(1,105$ reales and 6 maravedís); one staysail of fine canvas (1,739 reales); 84 varas of firstclass fine canvas no. 10, measuring 25 inches (882 reales); sixty-two sailmakers' needles (50 reales and 28 maravedís); one red banner (344 reales); one red flag ( 80 reales); ten pounds of 1-inch iron nails for pumps (41 reales and 6 maravedís); 24 fishhooks with their thimbles weighing 55 pounds ( 165 reales); twenty-four miscellaneous thimbles weighing 9 pounds ( 27 reales); thirty-three pounds of tanning extract ( 173 reales and 8 maravedís); six hundred pounds of pitch in four barrels (69o reales); twenty-five pounds of lampblack in one barrel with wooden hoops (30o reales); fifty pounds of linseed oil in four clay jars (216 reales); one boom, 44 inches thick and 18 cubits long (40o reales); one studding-sail mast, $2 \frac{3}{4}$ inches thick and 18 cubits long (40o reales); one iron brace weighing 12 pounds ( 36 reales); two iron bolts weighing 4 pounds (17 reales); two hoops weighing 3 pounds ( 7 reales); two hundred quintales of stones for ballast ( 55 reales). Plus ten percent for collection and storage charged to the Royal Treasury. Total 24,968 reales and 27 maravedís." " 18 remos de 13 pies de largo (que importaron en total 315 reales), 18 remos de 12 pies ( 315 rs), 4 vigotas ordinarias de 11 pulgadas ( $32 \mathrm{rs}$ ), 4 pastecas de 3 cajetas y 26 pulgadas cada una (106 rs), 1 cable de 14 pulgadas y 120 brazas de $2^{\text {a }}$ con peso de 3680 libras (14.6og rs), 480 brazas de veta alquitranada de 2 pulgadas y $3^{\text {a }}$ suerte, todo de 36 o libras de peso (1.105 rs y $6 \mathrm{mrs}$.), 1 sobremesana de vitre de segunda suerte (1.739 rs), 84 varas de vitre de $1^{\text {a }}$ clase $n^{\circ}$ 10, de 25 pulgadas ( $882 \mathrm{rs}$.), sesenta y dos agujas de vela (50 rs y $28 \mathrm{mrs}$ ), una bandera roja (344 rs), un gallardete rojo (8o rs), 10 libras de clavo de hierro para bomba de 1 pulgada (41 rs y 6 mrs.), 24 ganchos con sus guardacabos de 55 libras de peso (165 rs), 24 guardacabos sueltos con peso de 9 libras (27 rs), 33 libras de curtido correhuela (173 rs y $8 \mathrm{mrs}$ ), 6 oo libras de alquitrán en 4 barriles ( 690 rs), 25 libras negrohumo en 1 barril con arcos de madera (30o rs), 50 libras de aceite de linaza en 4 botijas de barro ( $216 \mathrm{rs}$ ), 1 botabara de popa de 44 pulgadas de grueso y 18 codos de largo (400 rs), 1 palo de rastreras de $23 / 4$ pulgadas de grueso y 18 codos de largo (40o rs), 1 abrazadera de hierro de 12 libras de peso ( $36 \mathrm{rs}$ ), dos pernos de hierro con 4 libras de peso (17 rs), dos zunchos con 3 libras de peso ( $7 \mathrm{rs})$, 200 quintales de lastre en piedra ( $55 \mathrm{rs}$ ). Más el $10 \%$ de todo lo cargado que se vende por la Real Hacienda, acopio y almacenaje (2.269 rs y $30 \mathrm{mrs}$ ). Total, 24.968 reales y 27 maravedíes"): AHN, Estado, leg. 4343.

174 "141 quintales, 5 pounds and 12 ounces of firewood (846 reales and 11 maravedís); 30 quintales, 72 pounds of ship's biscuit ( 4,915 reales and 6 maravedís); 18 quintales, 87 lbs. and 6 oz. of salt meat ( 4,529 reales and 23 maravedís); 17 quintales and 11 lbs. of rice $(3,969$ reales and 17 maravedís); three celemines [each about 4.6 liters] of salt (9 reales and 18 maravedís); 9 casks of meat ( 54 reales); 3 casks of dried peas ( 54 reales); one copper pump 
the goods that individual suppliers brought to the captain: 2,245 reales and 28 maravedís. ${ }^{175}$

TABLE 5 Expenses incurred by Mate Flores in El Ferrol, 1807

\begin{tabular}{lcc}
\hline Summary & Reales & Maravedís \\
\hline For the royal shipyards & 24,968 & 27 \\
For provisions & 14,399 & 7 \\
For health and private contractors & 2,245 & 28 \\
TOTAL & 39,368 & \\
\hline
\end{tabular}

SIGNED BY BERNARDINO REGUEIRO, AHN, ESTADO, LEG. 4343

This case is clearly emblematic of the problems caused by some Moroccan ships' captains in Spanish ports. ${ }^{176}$ They either did not have or claimed not to

(15 reales); one tin pump (6 reales). Total 14,399 reales and 7 maravedís" ("141 quintales 5 libras y 12 onzas de leña ( 846 reales y 11 maravedís), 3 o quintales 72 libras 5 libras bizcocho ordinario ( 4.915 rs y 6 mars), 18 qintales 87 libras 6 onzas carne salada (4.529 rs y 23 mrs), 17 quintales y 11 libras arroz ( 3.969 rs y 17 mrs), 3 celemines de sal ( 9 rs y 18 mrs), 9 barricas de las carnes ( $54 \mathrm{rs}$ ), 3 barricas de menestra ( $54 \mathrm{rs}$ ), 1 bomba de cobre ( 15 reales), 1 bomba de oja (6 reales). Total, 14.399 reales y 7 maravedíes"): El Ferrol, 17 September 1807, AHN, Estado, leg. 4343 .

175 The subtotal of 2,245 reales and 28 maravedís derived from the following: two receipts from Captains José Balay and Jacinto Pérez for chartering their boats and four sanitary inspectors for seventeen days at 50 reales, and two more at 40 reales, for 930 reales total; 628 reales and 20 maravedís for 205 1/2 pounds of tallow, to Pastor Villamontes; 455 reales to Ángel García for two arrobas of soap and 100 cabbages; 232 reales and 28 maravedís to Simón de Marcos for "two fanegas of salt, 36 dozen onions, three dozen brooms, a slate, paper, wafers, and pens." $\mathrm{N}^{\circ} 3$ : “Noticia de los recibos que ha satisfecho el que firma por los gastos ocasionados y efectos remitidos al Capn. Mate Flores de la Corverta de guerra Marroqui nombrada la Suera que ha estado fondeada en este Puerto desde el 15 de Agosto hasta el 6 de setiempre de este presente año," Francisco de Mendieta, El Ferrol, 8 September 1807, AHN, Estado, leg. 4343.

176 Francisco de Mendieta reported that "the Moroccan war corvette named La Suera has sailed, which had entered this port as I informed Your Excellency on 22 August, with all the demands of its captain, to which you responded on the 6th of this month, as I will report to my government. And as to what the governor relates about the carelessness of the missives the captain sent him, and the compensation he requests (which I consider fair) of the sum that he has provided for the expenses of the health authorities and other goods supplied to the warship, please make what disposition is pleasing to you” (“..."haverse hecho á la vela la Corbeta de Guerra Marroqui nombrada la Suera, que había entrado 
have the means of acquiring the victuals and supplies they needed. The authorities in the ports they visited resisted providing all those materials gratis, and in many cases did not even have them available.

\subsection{Algerian, Tripolitan, and Tunisian Corsair Captains}

Corsair ships from Algiers, Tripoli, and Tunis also frequented Spanish ports; although we have less information about them, they were admitted and treated there under much the same conditions as Moroccan vessels. The Treaty of Peace signed by Spain and Tripoli in 1784 stipulated that corsair ships of that regency would be allowed into Spanish ports, where they would be "supplied with all necessities, to be paid for at regular prices." If a Tripolitan vessel should run aground it would pay for any help given by the Spanish, unless the hosts waived the costs. ${ }^{177}$ The treaty of 1786 with Algiers established that Algerian ships would be allowed into Spanish ports when "they are obliged to enter them because of weather, or need repairs, or are being pursued by enemies"; but "help and other things they may need" would have to be paid at current prices. ${ }^{178}$ The treaty of 1791 with Tunis, while its terms were somewhat more vague, contained similar provisions. ${ }^{179}$

We still have few data about stops by North African corsair ships in Spanish ports. In the period $1790-1807$ Tunisian vessels entered the port of Barcelona at least twenty-two times, but Algerian ones did so on only three occasions. ${ }^{180}$ We know little about similar visits to Málaga, Palma de Mallorca, Cádiz, and other ports.

There do not seem to have been many incidents associated with these visits; most had to do with violations of health regulations, and others with captains' requests for free provisions. Evidently the language of the respective treaties

en aquel Puerto, de que di parte a V.E. en 22 de Agosto ultimo, como de las pretensiones de su Capitán, á que V.E. se sirve contextarme en 6 del actual, que tendré presente para mi gobierno. Y en quanto a lo mas que expone el referido gobernador sobre la falta de atención en los oficios que le pasó dicho Capitan, y reintegro que solicita (y hallo justo) de la cantidad que con las formalidades debidas ha suplido para los gastos de Sanidad y otras cosas subministradas al citado Buque, se dignará V.E. providenciar lo que fuere de su mayor agrado"): Francisco de Taranco to Pedro Cevallos, La Coruña, 19 September 1807, AHN, Estado, leg. 4343 .

177 Conrotte, España y los países musulmanes, 411-22.

178 Conrotte, España y los países, 439-48.

179 Conrotte, España y los países, 459-71.

180 Martín Corrales, "Il comercio della Catalogna" and "El comerç de Catalunya." 
was clearer and helped to avoid the kinds of situations that Moroccans had provoked.

After Algiers signed its Treaty of Peace and Friendship with Spain in 1786, its corsair vessels cruised the Spanish coasts to pursue and capture ships of nations with which Spain was at war. One of the consequences of this activity was a threat to sanitary regulations: the corsairs came into contact with Spanish ships, and often landed at different spots on the coast to load supplies and provisions. For the Catalan Board of Health (Junta de Sanidad de la Real Audiencia de Cataluña), these actions constituted a danger to public safety.

Further, the Algerians often tried to obtain supplies without payment. Baron Serrahí of the royal appeals court (Audiencia) of Barcelona lamented in July 1786

the ease with which Algerian corsairs abuse the welcome we have offered them in some of our ports: they demand without charge the green vegetables and other refreshments that have been supplied to them up to now. It has been necessary to explain to them that hitherto, when there was only a kind of cease-fire, these attentions were accepted; but that from now on they will be given what they request only upon payment, in accordance with the treaty of peace that has just been concluded and will soon be published. ${ }^{181}$

He was correct in his assessment. In June of that year an Algerian corsair galliot under Captain Soliman, with a crew of sixty, entered the port of Los Alfaques near Tarragona, asking for admission and free supplies of food; it claimed to have been admitted under those conditions to Benidorm, where its sailors had danced with local women. The Supreme Board of Health expressed alarm at "such liberties and licentious acts": aside from their indecency and sinfulness, they might give rise to "contagion and pestilence with a deadly and rapid progress." It noted that there was an epidemic in Bône at that very moment, and that by the treaty Algerians could enter only the ports of Barcelona, Alicante, and Málaga; it therefore forbade any contact with the Algerians. According to

181 “...la facilidad con que los Corsarios Argelinos abusan del agasajo, que se les há hecho en algunos de nuestros Puertos, pidiendo gratis, verduras, y otros refrescos, que se les han dado hasta aquí, se ha tomado la providencia de que se les haga entender que antes de ahora, que solo havia una especie de tregua, han podido pasar estas atenciones, pero que en lo sucesivo solo se les suministrará lo que pidiesen, pagándolo, y esto con arreglo al tratado de Paz, que acaba de concluirse, y que se publicará presto": Baron Serrahí to the Barcelona board of health, 12 July 1786, IM HB, FS, Serie I, leg. 17, fol. 108. 
the Board the king had ordered coastal batteries prepared to prevent similar landings. Still, it would permit the ship to be supplied "in good faith, although the Algerian does not show any," as long as it offered payment. ${ }^{182}$

In August 1787, while plague was suspected in Algiers, an Algerian galliot sailed into Sant Feliu de Guíxols and asked to stay until nightfall on the pretext of needing water, firewood, and bread. The village offered to sell them the supplies if they would depart at once, but in the end they sailed without obtaining anything while "a Moor of the ship's company threatened that merchant ships would pay the consequences." ${ }^{183}$ In that same month a small sloop, captured by Algerians a week before off Tortosa, entered a bay called Cala Rafalet, an hour distant from Mahón. When the health authorities on that coast either did not see it or ignored it, three North African crewmen debarked and reached Villa Carlos (modern Es Castell), where they were arrested. There was doubt as to whether "they had brushed against a basket of fruit carried by a woman they met along the way, and who was placed under quarantine": they were forced to board and sail with their ship. ${ }^{184}$

Similar incidents occurred in 179o. In June an Algerian galliot under Captain Fivimar dropped anchor in Cala Giverola, at Tossa, to take on wood and water; but on sailing it left behind one crewman, who was placed under quarantine at a hut on the beach. He first claimed to have fallen asleep, but later confessed that he had stayed behind on purpose and that "he had been punished." When the galliot demanded his return it was denied: the man fell under the authority of Gerona's city magistrate (corregidor), who delayed giving him up until he had served forty days' quarantine.

That same galliot tried to force a tartane from Sant Feliu, also anchored in Cala Giverola, to give it a launch, but the Catalan captain resisted. When sheriffs, troops, and local peasants arrived at the beach with supplies for the Algerian vessel they saw that it had seized the tartane's launch by sending some of its crew to swim for it. Asked for his reasons, the Algerian captain replied that he needed it to land, collect firewood, and cook some food, and claimed that Spaniards did the same on his native shores. ${ }^{185}$

On 19 June an Algerian corsair galliot anchored off Palamós, and several crewmen swam ashore before anyone could prevent them. They asked for water, wood, meat, and fruit. Challenged on their actions, they replied as in the

182 Iм нв, FS, Serie I, leg. 17, fols. 126-28; report of June 1786; Serie V, leg. 12, fol. 5, 14 June 1786.

183 The incident occurred on 12 August: Ім нв, FS, Serie v, leg. 12, fols. 68-69, 22 August 1787.

184 The event occurred on 18 August: Baron Serrahí to the Junta de Sanidad of Barcelona, 4 September 1787, Iм HB, FS, Serie I, leg. 18, fol. 137 .

185 The events occurred on 3 June: IM HB, FS, Serie v, leg. 12, fols. 129-30, 3 July 179 o. 
previous case: that Spaniards did the same in Algiers, and that the mutuality was justified. The health authorities in Palamós were prepared to use force in future incidents. The Supreme Board ordered that the ship be provisioned and its captain be made to understand the health regulations, but was willing to apply force if necessary. ${ }^{186}$

The city council of Lloret de Mar reported that on 3 June 1790 three Algerian galliots had anchored on its beach. Their captain, Majamed, had requested a new lateen-yard, twelve water casks, oil, and firewood. The council provided it all within twenty-four hours and "with due attention," following the royal decree of 28 May 1786; it then requested compensation of fifty-five libras, five sueldos and six dineros from the Board of Health. The Board claimed not to have the funds, but knowing that such cases needed some resolution it passed the bill to the supply officer (intendente); the latter, however, thought that the city council should bear the cost. ${ }^{187}$

In 1799 quarantine was imposed on the Tunisian captain Haggi Abdala for having landed in a launch from a Ragusan ship. ${ }^{188}$ The Algerian captain Amet Ben Mustafa of the polacre Mesahoda, 1,500 quintales, arrived in Tarragona in December 1807; he carried 410 Algerian quintales of cod and four casks of sardines, all bought in Algiers. According to his patent and health documents he had stopped in Peñíscola (where he had been allowed into port after nine days in quarantine) and Los Alfaques. He appealed to the governor of Tarragona "to act as my consul," because

in the five days we have spent at anchor in this port we still have not received permission to enter, nor any reply at all. Tonight we had a reply from the captain of the port [saying] that you order us to proceed from here to Barcelona to finish serving the quarantine. I hope that by your goodness you will admit us here, because otherwise it would cause great prejudice and delay both to me and to you: you must be aware that I have come here on purpose to load and unload in this port. ${ }^{189}$

\footnotetext{
186 Імн В, FS, Serie V, leg. 12, fols. 130-31, 3 July 179 .

187 Iм нв, FS, Serie v, leg. 12, fols. 137-38, 28 July 179 o.

188 The Ragusan captain was Juan Montenegro: Імнв, FS, Serie I, leg. 21, fol. 130, 25 September 1799 .

189 “...cinco días que estamos anclada en este Puerto aun no hemos tenido el logro de la entrada ni respuesta alguna en esta misma noche que tuvimos la respuesta del Capitán del Puerto que V.S. manda que se havia de ir de esta a Barcelona a concluir la quarentena espero de la bondad de V.S. nos admita en esta a libre platica porque del contrario seria un gran perjuhisio y atraso para mi como a V.S. no puede ignorar que desde aquella he venido â propósito para cargar y descargar en esta misma." The statement of Captain Amet Ben
} 
When the ship reached Tarragona the health authorities told the captain that every ship reaching Catalan waters must first proceed to Barcelona, the only port prepared to receive vessels from North Africa: having passed inspection ships could land at any Catalan port. The captain refused to go on to Barcelona, claiming he would prefer to see his ship sunk. While consulting their superiors about whether they should use force, the local officers assured the Algerian that they would do nothing of the kind, "out of respect for humanity." It was decided that the ship should obey a strict quarantine, at the end of which it would be allowed to unload and find new cargo but without formal entry into the port. ${ }^{190}$ The captain submitted a new statement that offered prudent reasons for not going on to Barcelona:

We are at war with three powers, the Portuguese, Tunisians, and Sardinians; and I have had word that two corsairs of the last of these powers are awaiting me between this port and that. Besides, if an English ship should find me going from one enemy port to another it could seize my warship and cargo. Therefore, if I leave this [port] for that one the loss of my vessel is inevitable, and perhaps my life and that of my crew also.

The Algerian's fear was palpable. It is likely that his ship was sailing under a false flag, probably Spanish, even though the captain claimed that he owned the vessel and that the crew consisted only of "ten Christians and the Moorish captain, making a crew of eleven individuals altogether."191

All ships' captains and owners violated the health regulations whenever they could, since the cost of obeying them reduced profits for everyone; that gave rise to incidents such as those we have just described. In November 1805

Mustafa was written by the ship's scribe, Juan Bautista Renelly, and addressed to the governor of the port of Tarragona: Puerto de Tarragona, 9 December 1807, IM HB, FS, Serie I, leg. 28 , fols. $146-48$.

190 Count of Santa Clara to Marquis of Vallesantoro, 22 December 1807; Ignacio Correa to Count of Santa Clara, Tarragona, 11 December 1807; Ramón Ansotegui, Board of Health (Diputación de Sanidad), to Pedro Ignacio Correa, Tarragona, 11 December 1807, IM HB, FS, Serie I, leg. 28 , fols. $146-48$.

191 "T] $]$ enemos guerra con tres potencias à saber Portugueses, Tunecinos y Sardos, dos corsarios de esta ultima potencia tengo informes me estan esperando entre esta y esa. A mas que si algun ingles me encontrare iendo de un puerto a otro enemigo haría buena presa de mi buque y cargo. Asi saliendo de esta para esa mi perdición de buque y cargo es inevitable y quizás mi vida y la de mi tripulación. ... diez christianos y el Rais Moro, que hacen con todos once individuos de tripulación." In the second statement, which affirmed that the captain owned the ship, the scribe declared that he signed the reports because the captain did not know how to write: 19 December 1807. 
the Spanish trade representative in Algiers, José Alonso Ortiz, sent a report to Pedro Ceballos in an Algerian xebec with orders to post it from the first Spanish port where the ship landed. The report notes that when three Algerian corsairs had arrived recently in Barcelona without any documentation at all, they had been made to serve the quarantine; Ortiz added that Algerian captains often refused to accept the documents they were offered. He concluded that the problems they encountered in Spanish ports came from their increasing impertinence in flouting the rules. ${ }^{192}$

There were a fair number of incidents involving North African ship captains between 1767 and 1814, and although our sources reveal a few surprising cases, most do not appear to have been of great significance. Some, as we have seen, resulted from a few captains' belief in their right to free food, equipment, and repairs. These men frivolously and maliciously tried to assume as an obligation what had originally been intended as simple, and limited, acts of courtesy.

Relations between the countries did not suffer, because both sides had an interest in ensuring their mutual cooperation. Captains or arraeces were important figures in Morocco at the time: they were often named ambassadors or special envoys, and occasionally became governors of cities. It behooved Spanish officials to keep them satisfied (gustosos, in the parlance of the day); therefore Spain tolerated their demands, however excessive and insolent they might be. Even when a captain's conduct went truly beyond the pale, Spain would usually ask the sultan to show him clemency. Nonetheless, not all of those who enjoyed Spain's generosity and advocacy became defenders of Spanish interests.

We have observed how the sultan of Morocco and his officials almost always tried to avoid clashes with the Spanish authorities. They issued frequent orders forbidding their ships to enter Spanish ports, to the great detriment of captains who might be in trouble - especially because those ports were so nearby that stopping in them could prove absolutely necessary. Harsh punishments might be meted out to important leaders of the navy.

In sum, captains caused conflicts through their belief that Spanish authorities should grant them everything they asked for: food, technical help, and materials to repair their damaged ships. Some acted with malice, taking advantage of ambiguity in the relations between the countries, characterized by

192 Dated at the end of 1805, IM Hв, FS, Serie I, leg. 27, fol. 202. 
the custom of the gift and counter-gift. We saw how some diplomatic envoys of the Moroccan sultan behaved in similar fashion. Yet it bears repeating that the sovereigns of Spain and Morocco, with their governments, made every effort to keep unpleasant incidents from troubling the friendly relations between the two countries. 